\title{
THERMAL, MECHANICAL AND BIODEGRADATION STUDIES OF BIOFILLER BASED POLY-3-HYDROXYBUTYRATE BIOCOMPOSITES
}

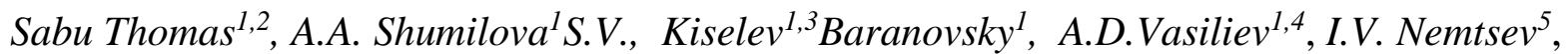 \\ E.G., A.P. Kuzmin ${ }^{1}$, A.G. Sukovatyi ${ }^{1,3}$, , R. Pai Avinash ${ }^{2}$, T.G. Volova ${ }^{1,3}$ \\ ${ }^{1}$ Siberian Federal University, 79 Svobodnyi Av., Krasnoyarsk 660041, Russia \\ ${ }^{2}$ International and Interuniversity Centre for Nano Science and Nano technology, Kottayam, \\ Kerala, India \\ ${ }^{3}$ Institute of Biophysics SB RAS, Federal Research Center "Krasnoyarsk Science Center SB \\ RAS”, 50/50 Akademgorodok, Krasnoyarsk 660036, Russia \\ ${ }^{4}$ L.V. Kirensky Institute of Physics SB RAS, Federal Research Center "Krasnoyarsk Science \\ Center SB RAS",43/50 Akademgorodok, Krasnoyarsk, 660036, Russia \\ ${ }^{5}$ Federal Research Center Krasnoyarsk Scientific Center of the Siberian Branch of Russian \\ Academy of Sciences, 50 Akademgorodok, Krasnoyarsk 660036, Russia
}

\begin{abstract}
Biodegradable poly-3-hydroxybutyrate $[\mathrm{P}(3 \mathrm{HB})]$ and natural materials (fillers) - clay, peat, and birch wood powder - were used to prepare powdered blends and, then, pellets and granules. Pellets were produced by cold pressing of polymer and filler powders; granules were produced from the powders wetted with ethanol. Properties of initial $\mathrm{P}(3 \mathrm{HB})$ and fillers and blends thereof were studied using IR spectroscopy, DSC, X-ray analysis, and electron microscopy. No chemical bonds between the components were revealed: the blends were physical mixtures. The degree of crystallinity of the blends was lower than that of the initial polymer, suggesting different crystallization kinetics of the blends. Introduction of increasing amounts of the fillers into the polymer progressively decreased mechanical strength of the pellets, as confirmed by the decrease in Young's modulus. The study of degradation of the blends in soil showed that the mass loss of the blends over 35 days of incubation in soil varied between 30 and $50 \%$ of the initial mass of the products, depending on the type of the filler.
\end{abstract}

Keywords: $P(3 H B)$, fillers, wood flour, clay, peat, polymer blends, physicochemical properties, degradation in soil

\section{Introduction}

The concept of sustainable development is the basic idea of the $21^{\text {st }}$ century. New methods of economic management should decrease the rates of consumption of nonrenewable fossil resources, preserving them for future generations, enable more effective use of energy resources, and introduce new, functional, and environmentally friendly recyclable materials in industrial production. Annual production of synthetic plastics has exceeded 320 million tons, and they largely accumulate in landfills, occupying fertile arable lands. Plastic wastes ruin municipal sewage and drainage systems. Up to $10 \%$ of the annual plastic production leaks into the Global Ocean [1,2]. Therefore, development of new environmentally friendly materials, which will be able to be completely degraded in the environment without releasing toxic products, joining the global cycles, is among the priorities for critical technologies of the $21^{\text {st }}$ century at the international level.

Industrial ecology and green chemistry are tools for creating new ecofriendly materials including those manufactured from renewable sources [3]. Hybrids based on synthetic polyolefins and natural materials have been increasingly used in various applications. Polymers synthesized by living systems, the so-called biopolymers, have attracted considerable attention, too. Among various natural materials, a special place is occupied by polyhydroxyalkanoates (PHAs) - microbial polymers that can be used in different areas, primarily in medicine. PHAs 
are degraded to harmless products $\left(\mathrm{CO}_{2}\right.$ and $\left.\mathrm{H}_{2} \mathrm{O}\right)$; they are biocompatible, mechanically strong, thermoplastic, capable of blending with other materials, and processable by conventional methods from different phase states [4-9].

Recently, degradable materials have been used to construct ecofriendly new-generation formulations to protect crops and reduce the risk of uncontrolled spreading of pesticides and accumulation thereof in the biosphere [10]. PHAs have been studied as candidates for this application. Suave et al. [11] described $\mathrm{P}(3 \mathrm{HB})$ microparticles loaded with the insecticide malathion. Hydroxybutyrate-co-hydroxyvalerate copolymers were used as carriers for the herbicides atrazine and ametryn [12-14]. A series of studies described $\mathrm{P}(3 \mathrm{HB})$ microparticles, granules, films, and pellets loaded with the herbicide metribuzin and the fungicide tebuconazole; release kinetics of the active ingredients and degradation of the polymer matrix were investigated in soil microecosystems [15-17]. The efficacy of the formulations was evaluated in laboratory wheat ecosystems contaminated with weeds and infected with fusarium pathogens [18-19].

However, the high cost hinders the use of PHAs in technical applications such as agriculture (films and pots for greenhouses, carriers for fertilizers and agrochemicals); production of packages, containers, and household goods; construction industry; etc., which require very large amounts of material. PHA cost can be reduced by upgrading production processes and by using cheaper substrates. Another approach is to use PHA blends with cheaper materials: this can both reduce the cost of the material and modify the properties of the polymers. Most of the available studies, however, describe blends of degradable poly-3-hydroxybutyrate with the soluble companion polymers - polylactide and polyglycolide, polycaprolactone, polyaniline, etc., which are mainly intended for producing medical devices and preparations in the form of films, nonwoven membranes, and microparticles for drug delivery.

There are few published data on production and properties of PHA blends with solid phase fillers. Some relatively recent studies investigated natural materials as fillers for modifying properties of PHAs. They described results of filling polyhydroxyalkanoates with clay and its derivatives [20-23], plant fibers [24,25], lignin and holocellulose from a lignocellulosic biowaste [26], and wood chips and powder [27-29]. As those studies describe different methods of production and investigation of PHA-based blends, it is difficult to compare them and draw any conclusion about the consistent effects of the fillers on the properties of these polymers.

The purpose of this study was to produce PHB biocomposites using clay, peat and wood flour as biofillers and to study its thermal, mechanical and morphological properties.

\section{Experimental}

\subsection{Materials}

Samples of $\mathrm{P}(3 \mathrm{HB})$ were synthesized by using the Cupriavidus eutrophus B10646 wildtype strain, at the Institute of Biophysics SB RAS. Cells were batch-cultured under strictly aseptic conditions, following the previously developed technology [30-31]. Polymer was extracted from cells with chloroform, and the extracts were precipitated using hexane. The extracted polymers were re-dissolved and precipitated again 3-4 times to prepare homogeneous specimens. The composition of polymers was analyzed with a GC-MS (6890/5975C, Agilent Technologies, U.S.).

Three natural materials were used as fillers: peat, wood flour and clay. High-moor peat "Agrobalt-N", state registration 0428-06-209-139-0-0-01, was produced by OOO "Akademiya tsvetovodstva", Russia). Wood flour was produced by grinding wood of birch (Betula pendula Roth) using an MD 250-85 woodworking machine ("StankoPremyer" Russia). Then it was dried at $60^{\circ} \mathrm{C}$ for $120 \mathrm{~h}$ until it reached constant weight, and $0.5 \mathrm{~mm}$ mesh was used to separate the particle size fraction. Clay was taken from the mine "Kuznetsovskoye", the Krasnoyarskii Krai, Russia. Its composition: loss on ignition - $6.92 \% ; \mathrm{SiO}_{2}-60.1 \% ; \mathrm{Al}_{2} \mathrm{O}_{3}-19.17 \% ; \mathrm{Fe}_{2} \mathrm{O}_{3}-$ $6.72 \% ; \mathrm{CaO}-2.02 \% ; \mathrm{MgO}-2.12 \% ; \mathrm{SO}_{3}-0.65 \% ; \mathrm{Na}_{2} \mathrm{O}-0.88 \% ; \mathrm{K}_{2} \mathrm{O}-1.45 \%$. 


\subsection{Preparation of blends of $\mathrm{P}(3 \mathrm{HB})$ and natural materials and fabrication of pellets and granules}

The polymer and fillers were pulverized by impact and shearing action in ultracentrifugal mill ZM 200 (Retsch, Germany). To achieve high fineness of polymer grinding, the material and the mill housing with the grinding tools were preliminarily cooled at $-80^{\circ} \mathrm{C}$ for about $30 \mathrm{~min}$ in an Innova U101 freezer (NEW BRUNSWICK SCIENTIFIC, U.S.). Grinding was performed using a sieve with $2-\mathrm{mm}$ holes at a rotor speed of $18000 \mathrm{rpm}$. Fillers were not precooled before grinding; a sieve with 2-mm holes was used, and the grinding was performed at $6000 \mathrm{rpm}$. Fractionation of the polymer and filler powders was carried out using vibratory sieve shaker AS 200 control (Retsch, Germany). Fractioning time was $10 \mathrm{~min}$, amplitude $1.5 \mathrm{~mm}$; a $100 \mathrm{~g}$ sample was used. Fractions of the polymer and filler powders of $200 \mu \mathrm{m}$ and less were selected and used.

Then, polymer powder was mixed with different filler powders in benchtop planetary mixer SpeedMixer DAC 250 SP (Hauschild Eng., Germany); the blend time was 1 min, and the speed was $1000 \mathrm{rpm}$. The blends contained different amounts of the fillers: 10, 30, and 50\%.

The homogenized blends were used to produce pellets and granules. Pellets were prepared by cold pressing at 36 bar using a laboratory semiautomatic press (Minipress, Minsk, Belarus). Granules were prepared by mixing wet polymer paste $(40 \%)$ in ethanol in planetary mixer SpeedMixer DAC 250 SP (Hauschild Eng., Germany), with the mixing time 1 min at 1000 $\mathrm{rpm}$, and granulating in screw granulator Fimar EAC (Italy) with a $6 \mathrm{~mm}$ nozzle. The granules were dried in a fume hood at room temperature for $24 \mathrm{~h}$.

Poly-3-hydroxybutyrate, peat, clay, and wood powders, powdered $\mathrm{P}(3 \mathrm{HB}) /$ filler blends, and granules and pellets were examined by using state-of-the-art physicochemical methods.

\subsection{Experimental techniques \\ SEM microscopy}

The surface microstructure of pellets and granules prepared from blends was analyzed using scanning electron microscopy (a TM-3000 Hitachi microscope with the QUANTAX 70 program, Japan). Prior to microscopy, the samples were sputter coated with platinum (at $10 \mathrm{~mA}$, for $40 \mathrm{~s}$ ), with an Emitech K575XD Turbo Sputter Coater (Quorum Technologies Limited, U.K.). Elemental analysis of the samples was done using a scanning electron microscope equipped with a system for X-ray spectroscopy (a TM-3000 Hitachi microscope with QUANTAX 70 software).

\section{FTIR spectroscopy}

All initial materials and blends were analyzed using FTIR spectroscopy. IR spectra were taken in the 400-4000 $\mathrm{cm}^{-1}$ range using a "NICOLET 6700" FT-IR spectrometer (Thermo Scientific, U.S.) and a Smart Orbit accessory, by the attenuated total reflection (ATR) technique.

\section{Differential scanning calorimetry (DSC)}

Thermal analysis of the initial materials and blends was performed using a DSC-1 differential scanning calorimeter (METTLER TOLEDO, Switzerland). Powdered samples (4.0 $\pm 0.2 \mathrm{mg}$ each) were placed into the aluminum crucible and compressed prior to measurement. Every sample was measured at least 3 times. The specimens were heated at a rate of $5{ }^{\circ} \mathrm{C} / \mathrm{min}$ to $200{ }^{\circ} \mathrm{C}$, then cooled to $-20{ }^{\circ} \mathrm{C}$, held for 20 minutes and re-heated to $320{ }^{\circ} \mathrm{C}$. Glass transition temperature $(T g)$, crystallization temperature $(T c)$, melting point (Tmelt), and thermal degradation temperature (Tdegr) were determined from peaks in thermograms using the "StarE" software.

\section{$X$-ray diffraction $(X R D)$}

$\mathrm{X}$-Ray structure analysis and determination of crystallinity of initial materials and blends were performed employing a D8 ADVANCE X-Ray powder diffractometer equipped with a 
VANTEC fast linear detector, using CuKa radiation (Bruker, AXS, Germany). The samples had a circular shape because during measurement the sample spins in a direction perpendicular to the surface. The scan step was $0.016^{\circ}$, measurement time in each step $114 \mathrm{~s}$, and scanning range from $2^{\circ}$ to $60^{\circ}$ (from $48^{\circ}$ to $60^{\circ}$ there only was a uniformly decreasing background); the registered parameter was intensity of X-rays scattered by the sample; $55^{\circ} / 0.016^{\circ}=3438$ times. The degree of crystallinity was calculated as a ratio of the total area of crystalline peaks to the total area of the radiograph (the crystalline + amorphous components). Measurement accuracy: point measurement accuracy \pm 0.4 PPS, with the lowest intensity 1.5 PPS and the highest intensity 32 PPS; the error in determination of the degree of crystallinity, which was calculated based on multiple measurements, was $2 \%$ or less.

\section{Mechanical analysis}

Mechanical properties of the pellets and granules were investigated using an electromechanical tensile testing machine Instron 5565 (U.K.). At least five samples were tested for each blend type. Measurements were conducted at ambient temperature. The samples had a cylindrical shape $6 \mathrm{~mm}$ in diameter with and height of $4 \mathrm{~mm}$. The speed of the crosshead was 1 $\mathrm{mm} / \mathrm{min}$ at ambient temperature. Young's modulus (E, MPa) was automatically calculated by the Instron software (Bluehill 2, Elancourt, France). To obtain Young's modulus, the software calculated the slope of each stress-strain curve in its elastic deformation region. Measurement error did not exceed $10 \%$.

Moisture absorption was investigated gravimetrically in dynamic mode. The amounts of water absorbed by pellets and granules were measured 3,5 , and $24 \mathrm{~h}$ after contact with water.

\section{Degradation of samples in soil}

Pellets and granules were weighed, placed into nylon mesh bags, and buried in the field soil (200 g in $250-\mathrm{cm}^{3}$ containers) at a depth of $2 \mathrm{~cm}$. They were incubated in soil for 35 days at a temperature of $25{ }^{\circ} \mathrm{C}$ and soil moisture content of $50 \%$. The agro-transformed soil was collected at field laboratory "Minderlinskoye" of the Krasnoyarsk State Agrarian University (forest-steppe, $56^{\circ} \mathrm{N}, 92^{\circ} \mathrm{E}$, the Krasnoyarsk Territory, Siberia, Russia). The soil was chernozem with heavy loam particle-size composition, density of between 0.80 and $1.24 \mathrm{~g} / \mathrm{cm}^{3}, \mathrm{pH} 7.3$, with high contents of ammonium nitrogen $(35 \mathrm{mg} / \mathrm{kg})$ and nitrate nitrogen $(9.2 \mathrm{mg} / \mathrm{kg})$. The soil contained $280 \mathrm{mg} / \mathrm{kg}$ of phosphorus and $250 \mathrm{mg} / \mathrm{kg}$ of potassium.

Every 7 days, the specimens ( 3 in a bag) were removed from the soil to determine their mass loss - the parameter indicating biodegradation of pellets and granules.

\subsection{Statistics}

Statistical analysis of the results was performed by conventional methods, using the standard software package of Microsoft Excel. Arithmetic means and standard deviations were found. The statistical significance of results was determined using Student's test (significance level: $\mathrm{P} \leq 0.05$ ). Statistical analysis of surface properties of the samples was performed by using embedded methods of the DSA-4 software.

\section{Results and discussion}

\subsection{Characterization of $\mathbf{P}(3 \mathrm{HB})$ and initial natural materials}

Poly-3-hydroxybutyrate and natural materials (clay, peat, and birch wood flour) with considerably different properties (Table 1$)$ were used to produce $\mathrm{P}(3 \mathrm{HB}) /$ filler blends: fine powder and paste prepared with ethanol (40\% moisture content).

Table 1.- Physicochemical properties of initial materials and blends 


\begin{tabular}{|c|c|c|c|c|c|}
\hline Sample & $\mathrm{C}_{\mathrm{x}}, \%$ & $\begin{array}{l}\mathrm{T}_{\text {melt. }}, \\
{ }^{\circ} \mathrm{C}\end{array}$ & $\mathrm{T}_{\text {cryst.. }}{ }^{\circ} \mathrm{C}$ & $\begin{array}{l}\mathrm{T}_{\text {degr. }} \\
{ }^{\circ} \mathrm{C}\end{array}$ & $\begin{array}{c}\text { Melting } \\
\text { enthalpy, } \\
(\mathrm{J} / \mathrm{g})\end{array}$ \\
\hline \multicolumn{6}{|c|}{ Initial materials: } \\
\hline $\mathrm{P}(3 \mathrm{HB})$ & 75 & 176 & 108 & 287 & 89.3 \\
\hline clay & 53 & & & $200^{*}$ & \\
\hline peat & 9 & & & $130^{*}$ & \\
\hline wood flour & 26 & & & $220 *$ & \\
\hline \multicolumn{6}{|c|}{ Blends $(\mathrm{P}(3 \mathrm{HB}) /$ filler $=70 / 30):$} \\
\hline \multicolumn{6}{|l|}{$\mathrm{P}(3 \mathrm{HB}) /$ clay: } \\
\hline $90: 10$ & 72 & 177 & 110 & 286 & 52.4 \\
\hline $90: 30$ & 60 & 175 & 110 & 283 & 38.5 \\
\hline $90: 50$ & 56 & 176 & 109 & 276 & 29.8 \\
\hline \multicolumn{6}{|l|}{$\mathrm{P}(3 \mathrm{HB}) /$ peat: } \\
\hline $90: 10$ & 60 & 174 & 107 & 288 & 64.1 \\
\hline $90: 30$ & 48 & 176 & 108 & 292 & 59.7 \\
\hline $90: 50$ & 42 & 177 & 110 & 290 & 48.7 \\
\hline \multicolumn{6}{|l|}{$\begin{array}{l}\mathrm{P}(3 \mathrm{HB}) / \text { wood } \\
\text { flour: }\end{array}$} \\
\hline $90: 10$ & 65 & 178 & 107 & 279 & 66.9 \\
\hline $90: 30$ & 47 & 175 & 106 & 273 & 51.3 \\
\hline $90: 50$ & 44 & 171 & 104 & 274 & 45.4 \\
\hline
\end{tabular}

$\mathrm{P}(3 \mathrm{HB})$ is a highly crystalline material, with the prevailing crystalline phase, and its degree of crystallinity $\left(\mathrm{C}_{\mathrm{x}}\right)$ is usually above $60-65 \%$; the $\mathrm{C}_{\mathrm{x}}$ of the $\mathrm{P}(3 \mathrm{HB})$ sample used in this study is $75 \%$. X-ray diffraction pattern of $\mathrm{P}(3 \mathrm{HB})$ is shown in Figure 1a. Diffraction peaks in $2 \Theta$ $=13.4,16.8,20,22.2$ and $25.5^{\circ}$ have a similar pattern when compared with previous crystallographic data for this material [Ikejima, Inoue, 2000; Araujo et al., 2011].

$\mathrm{X}$-ray diffraction patterns of the fillers differed from the diffraction pattern of $\mathrm{P}(3 \mathrm{HB})$. Wood flour showed distinct diffraction peaks at $2 \theta=14.2,19.6$, and $25.5^{\circ}$, in contrast to the amorphized peat. X-ray examination of clay revealed numerous narrow diffraction peaks, and the most distinct one was at $23.5^{\circ}$. Clay had the highest $\mathrm{C}_{\mathrm{x}}(53 \%)$. In wood flour and, especially, peat, amorphous phase prevailed, and their degrees of crystallinity were low: 26 and 9\%, respectively.
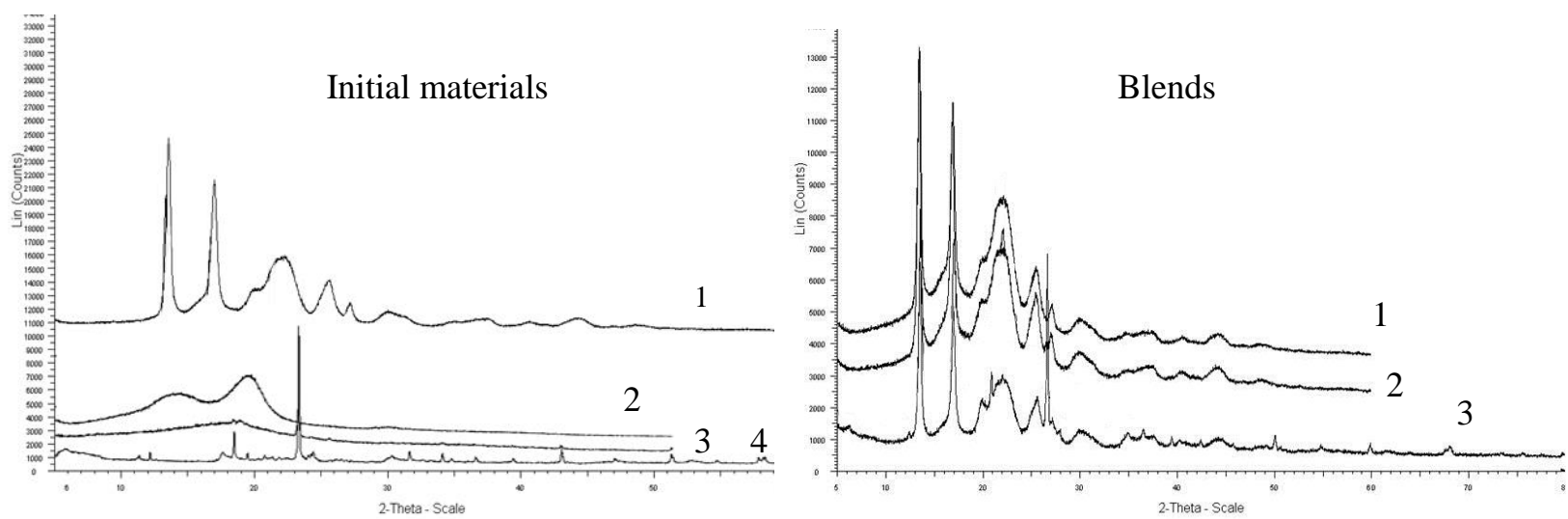

Fig. 1. X-ray diffraction patterns of initial materials: 1 - $\mathrm{P}(3 \mathrm{HB}) ; 2$ - wood flour; 3 - peat; 4 - clay; and blends $(\mathrm{P}(3 \mathrm{HB}) /$ filler $=70 / 30): 1-\mathrm{P}(3 \mathrm{HB}) /$ wood flour; $2-\mathrm{P}(3 \mathrm{HB}) /$ peat; 3 $\mathrm{P}(3 \mathrm{HB}) /$ clay 
Thermal properties of the polymer and fillers are different too (Fig. 2 a). $\mathrm{P}(3 \mathrm{HB})$ is a thermoplastic material, with a considerable difference between melting point $\left(176^{\circ} \mathrm{C}\right)$ and thermal decomposition temperature $\left(287^{\circ} \mathrm{C}\right)$. Its peak of thermal decomposition is in the $\ldots ? ?^{\circ} \mathrm{C}$ range, and the onset of the process is at $280^{\circ} \mathrm{C} . \mathrm{P}(3 \mathrm{HB})$ crystallization temperature is $108^{\circ} \mathrm{C}$ and melting enthalpy is $89.3 \mathrm{~J} / \mathrm{g}$. By contrast, none of the fillers is a thermoplastic material. Initial heating of these materials (and blends) gives a small peak at a temperature between 70 and $130^{\circ} \mathrm{C}$, which is associated with evaporation of moisture and volatile organic compounds (denoted by arrows in Fig. 2). After moisture evaporation, thermal decomposition of peat begins at $130^{\circ} \mathrm{C}$ and thermal decomposition of wood flour at $220^{\circ} \mathrm{C}$. For clay, at a temperature between 60 and $200^{\circ} \mathrm{C}$, moisture evaporates and decomposition and evaporation of volatile organic compounds begin (the process is endothermal); however, at temperatures between 200 and $400^{\circ} \mathrm{C}$, decomposition is accompanied by heat release.

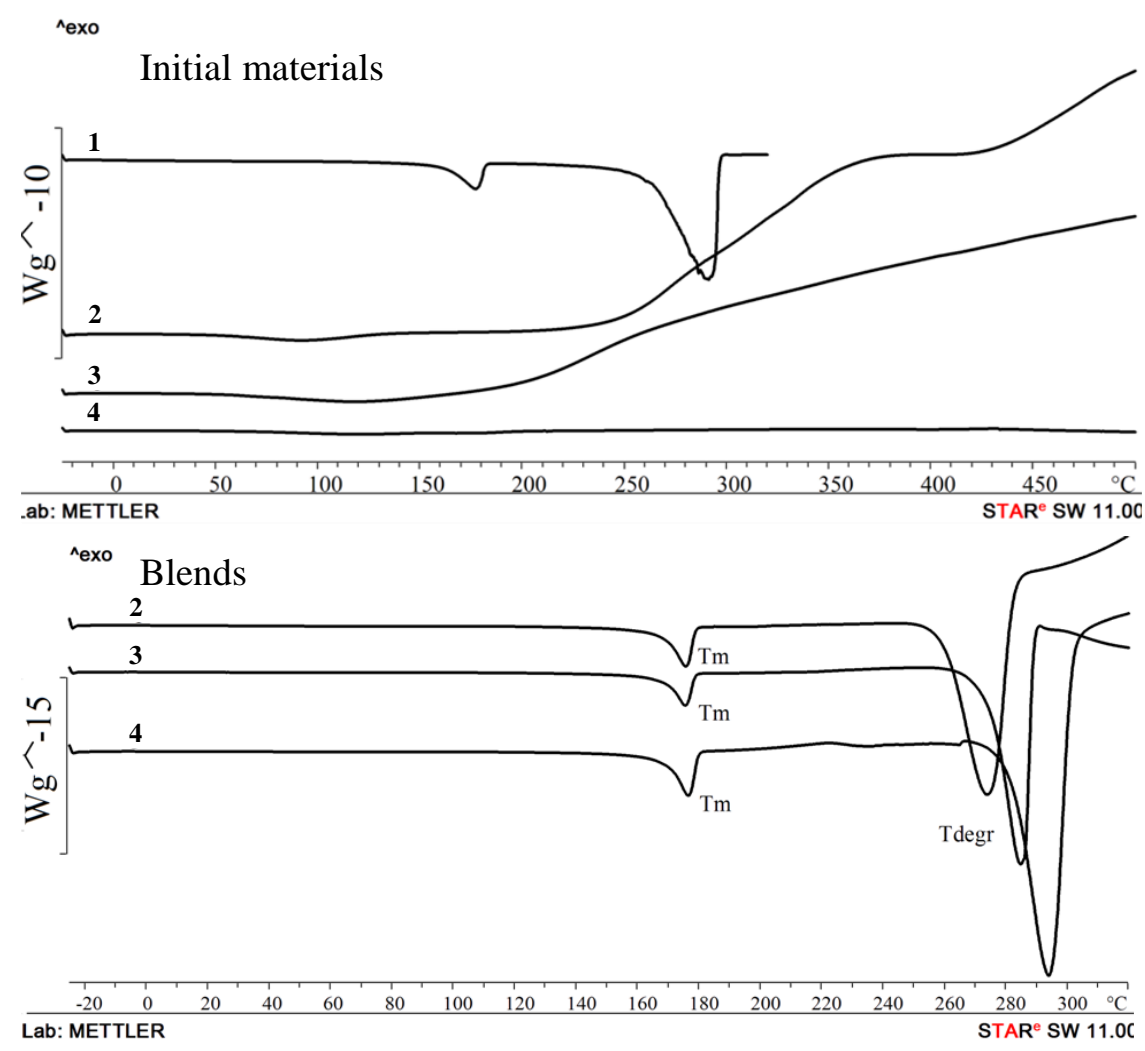

Fig. 2. DSC of initial materials: 1 - $\mathrm{P}(3 \mathrm{HB}) ; 2$ - wood flour; 3 - peat; 4 - clay; and blends $(\mathrm{P}(3 \mathrm{HB}) /$ filler $=70 / 30): 2-\mathrm{P}(3 \mathrm{HB}) /$ wood flour; $3-\mathrm{P}(3 \mathrm{HB}) /$ peat; $4-\mathrm{P}(3 \mathrm{HB}) /$ clay

Possible structural differences between the blends were detected using IR spectroscopy, which is employed to study the structures of various macromolecules. Variations in the intensity of the bands in the low-frequency range are indicators of both the crystalline to amorphous phase ratio in the blend and the type of interactions of the components in the blend.

FT-IR spectra of $\mathrm{P}(3 \mathrm{HB})$ and the three fillers were taken in the $400-4000 \mathrm{~cm}^{-1}$ range (Fig. $3)$. The spectra show not only the groups of carbon compounds $\left(\mathrm{C}=\mathrm{O}, \mathrm{C}-\mathrm{OH}, \mathrm{CH}_{2}, \mathrm{CH}_{3}\right)$ contained in all initial materials but also the groups and compounds characteristic of individual components. These are $\mathrm{CH}, \mathrm{CH} 2, \mathrm{CH} 3, \mathrm{C}-\mathrm{OH}$, and $\mathrm{COOH}$ groups for $\mathrm{P}(3 \mathrm{HB}), \mathrm{S}-\mathrm{S}-, \mathrm{C}=\mathrm{C}, \mathrm{C}=\mathrm{N}$, and $\mathrm{N}-\mathrm{H}$ groups for peat, $\mathrm{Si}-\mathrm{O}-\mathrm{Si}(\mathrm{AL})$ and $\mathrm{Fe}-\mathrm{O}$ in $\alpha-\mathrm{Fe}_{2} \mathrm{O}_{3}$ for clay, and $-\mathrm{C}-\mathrm{O}-;-\mathrm{C}-\mathrm{O}-\mathrm{C}-$ for birch wood flour. 


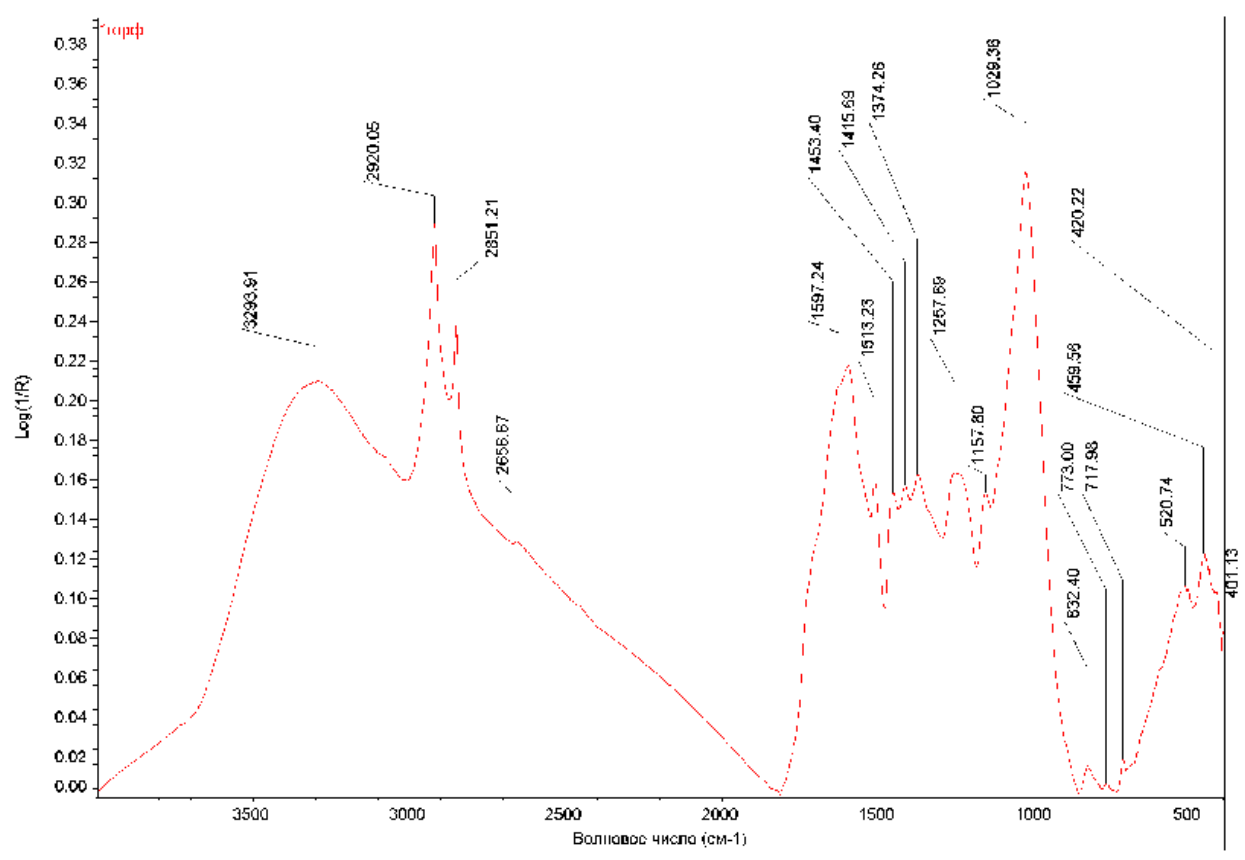

Fig. 3. FT-IR spectra of $\mathrm{P}(3 \mathrm{HB})$ and initial materials: clay, wood flour, and peat

The IR absorption spectra of $\mathrm{P}(3 \mathrm{HB})$ (Fig. 3 a) contain absorption bands corresponding to vibrations of the main structural components of polymers except the absorption bands of vibrations of the terminal $\mathrm{C}-\mathrm{OH}$ and $\mathrm{COOH}$ groups. The bands of the ordered optical densities (crystalline phase) are in the $1228 \mathrm{~cm}^{-1}$ range while the bands of the amorphous phase are shifted to $1182 \mathrm{~cm}^{-1}$. This is consistent with the data reported in other studies [32,33]. The spectra show distinct absorption bands of asymmetric stretching of $\mathrm{CH}_{3}-$ and $\mathrm{CH}_{2-}$ groups $\left(2978\right.$ and $2994 \mathrm{~cm}^{-}$ ${ }^{1}$ ); symmetric stretching of $\mathrm{CH}-$ and $\mathrm{CH}_{2}$ groups (2994 and $2934 \mathrm{~cm}^{-1}$ ); stretching of conjugated $\left(1687 \mathrm{~cm}^{-1}\right)$ and unconjugated $\left(1720 \mathrm{~cm}^{-1}\right)$ carbonyl groups $\mathrm{C}=\mathrm{O}$; skeletal $\mathrm{CH}$ vibrations (599 $\left.\mathrm{cm}^{-1}\right)$; and $\mathrm{CH}$ bending $\left(622 \mathrm{~cm}^{-1}\right)$. PHAs are hydrophobic compounds, in which molecules of water interact with the hydrogen atom of the methyl group or with the oxygen atom of the carboxyl group through hydrogen bonding. The narrow bands at $3436 \mathrm{~cm}^{-1}$ are typical of the hydrogen bonded $\mathrm{OH}$ group. The $1687 \mathrm{~cm}^{-1}$ band is characteristic of hydrogen vibration in the $\mathrm{OH}$ group interacting with the oxygen atom through hydrogen bonding. The 2874, 2934, 2978, and $2994 \mathrm{~cm}^{-1}$ absorption bands are typical of the bonded $\mathrm{OH}$ group and may be a component of the $\mathrm{COOH}$ dimer group. In the $3000-2500 \mathrm{~cm}^{-1}$ range, there is a group of weak bands typical of the dimers of carboxylic acids.

In contrast to $\mathrm{P}(3 \mathrm{HB})$ IR spectra, the IR spectra of peat (Fig. $3 \mathrm{~b}$ ) contain absorption bands of the $-\mathrm{S}-\mathrm{S}$ - bond groups $\left(521 \mathrm{~cm}^{-1}\right) ;-\mathrm{C}-\mathrm{O}$ - groups characteristic of carbohydrates (1029 $\left.\mathrm{cm}^{-1}\right)$; deformation vibrations of $-\mathrm{CH}_{2}$ - groups $\left(718 \mathrm{~cm}^{-1}\right)$; skeletal vibrations of the benzene ring $\mathrm{C}=\mathrm{C}$ (lignin), $\mathrm{C}=\mathrm{N}, \mathrm{N}-\mathrm{H}\left(1513\right.$ and $\left.1597 \mathrm{~cm}^{-1}\right)$, and stretching of the $-\mathrm{OH}$ groups at $3300 \mathrm{~cm}^{-1}$.

The IR spectra of clay (Fig. $3 \mathrm{c}$ ) contain absorption bands in the 776 and $795 \mathrm{~cm}^{-1}$ range, corresponding to stretching and symmetrical vibrations of $\mathrm{Si}-\mathrm{O}-\mathrm{Si}(\mathrm{Al})$ and $\mathrm{Fe}-\mathrm{O}$ in $\alpha-\mathrm{Fe}_{2} \mathrm{O}_{3}$; stretching vibrations of (AI-0), (Si-O-Al), and $-\mathrm{A}_{2} 2_{2}$ in the $692 \mathrm{~cm}^{-1}$ range. In the $978 \mathrm{~cm}^{-1}$ range, there are absorption bands corresponding to $(\mathrm{O}-\mathrm{Si})$ deformation vibrations. The absorption frequency observed at $1635 \mathrm{~cm}^{-1}$ is indicative of deformation vibrations of $\mathrm{H}-\mathrm{O}-\mathrm{H}$, which suggest water sorption on the surface of the mineral. The absorption band at 3615 and $3392 \mathrm{~cm}^{-1}$ corresponds to stretching and symmetric vibrations of AlO-H for clay bound water. The 3619 $\mathrm{cm}^{-1}$ band corresponds to stretching of intramolecular hydroxyls located on the surface of octahedral and tetrahedral sheets [34]. 
IR spectra of birch wood flour (Fig. 3 d) show plane bending of the guaiacyl ring of lignin of leaves $\left(1031 \mathrm{~cm}^{-1}\right)$, stretching of -C-O-;-C-O-C- $\left(1235 \mathrm{~cm}^{-1}\right)$, skeletal vibrations of the syringyl ring of lignin of leaves $\left(1324 \mathrm{~cm}^{-1}\right)$, stretching and skeletal vibrations of benzene ring (1422 $\left.\mathrm{cm}^{-1}, 1504 \mathrm{~cm}^{-1}, 1593 \mathrm{~cm}^{-1}\right)$, stretching of $-\mathrm{C}=\mathrm{O}$ of conjugated and unconjugated groups $\left(1652 \mathrm{~cm}^{-1}, 1734 \mathrm{~cm}^{-1}\right)$, and intramolecular and intermolecular stretching of $-\mathrm{OH}$ groups and water $\left(3337-3342 \mathrm{~cm}^{-1}\right)$.

\subsection{Characterization of $\mathbf{P}(3 \mathrm{HB}) /$ filler blends}

Powdered $\mathrm{P}(3 \mathrm{HB})$ and fillers were processed by cold pressing to produce pellets with a diameter of $6 \mathrm{~mm}$ and height $3 \mathrm{~mm}$ and granules with a diameter of $2 \mathrm{~mm}$ and length of between 2 and $4 \mathrm{~mm}$.

Elemental analysis of the samples was done using a scanning electron microscope equipped with a system for X-ray spectrometry (Table 2). The initial $\mathrm{P}(3 \mathrm{HB})$ contained only carbon (66.96 at.\%) and oxygen (33.04 at.\%). The $\mathrm{P}(3 \mathrm{HB}) /$ wood flour blend also contained silicon, aluminum, iron, calcium, and sulfur; $\mathrm{P}(3 \mathrm{HB}) /$ peat blends additionally contained $\mathrm{Mg}$ and $\mathrm{K}$. The elemental composition of $\mathrm{P}(3 \mathrm{HB}) /$ clay blends was the most diverse. They contained 11 elements: in addition to the elements mentioned above, analysis detected sodium, titanium and manganese.

Table 2.- Elemental composition of $\mathrm{P}(3 \mathrm{HB})$ and blend $(\mathrm{P}(3 \mathrm{HB}) /$ filler $=70 / 30)$ samples (atomic $\%)$

\begin{tabular}{|l|l|l|l|l|}
\hline Element & $\mathrm{P}(3 \mathrm{HB})$ & $\begin{array}{l}\mathrm{P}(3 \mathrm{HB}) / \text { wood } \\
\text { flour }\end{array}$ & $\mathrm{P}(3 \mathrm{HB}) /$ peat & $\mathrm{P}(3 \mathrm{HB}) /$ clay \\
\hline $\mathrm{C}$ & $66.96 \pm 6.5$ & $67.03 \pm 6.4$ & $63.32 \pm 6.2$ & $44.80 \pm 3.8$ \\
\hline $\mathrm{O}$ & $33.04 \pm 4.5$ & $32.03 \pm 4.2$ & $36.52 \pm 4.9$ & $43.39 \pm 4.7$ \\
\hline $\mathrm{Si}$ & - & 0.26 & 0.03 & $6.71 \pm 0.5$ \\
\hline $\mathrm{Al}$ & - & 0.13 & 0.02 & $2.98 \pm 0.2$ \\
\hline $\mathrm{Fe}$ & - & $0.22 \pm 0.1$ & - & $0.84 \pm 0.1$ \\
\hline $\mathrm{Mg}$ & - & - & 0.03 & $0.41 \pm 0.1$ \\
\hline $\mathrm{K}$ & - & - & 0.07 & 0.34 \\
\hline $\mathrm{Ca}$ & - & 0.26 & - & 0.29 \\
\hline $\mathrm{Na}$ & - & - & - & 0.12 \\
\hline $\mathrm{Ti}$ & - & - & - & 0.09 \\
\hline $\mathrm{Mn}$ & - & - & - & 0.05 \\
\hline $\mathrm{S}$ & - & 0.08 & - & - \\
\hline
\end{tabular}

(-) not detected

Morphology of blends.

Pellets and granules prepared from blends with fillers that had different properties exhibited diverse surface structures (Fig. 4). SEM images showed porous and rough surface microstructures. The surface of the $\mathrm{P}(3 \mathrm{HB}) /$ wood flour pellets showed rectangular sawdust particles embedded in the surface layer; on the surface of the $\mathrm{P}(3 \mathrm{HB}) /$ peat pellets, there were asymmetrical heteraxial inclusions. On $\mathrm{P}(3 \mathrm{HB})$ /clay pellets, clay inclusions were uniformly distributed over the surface. 

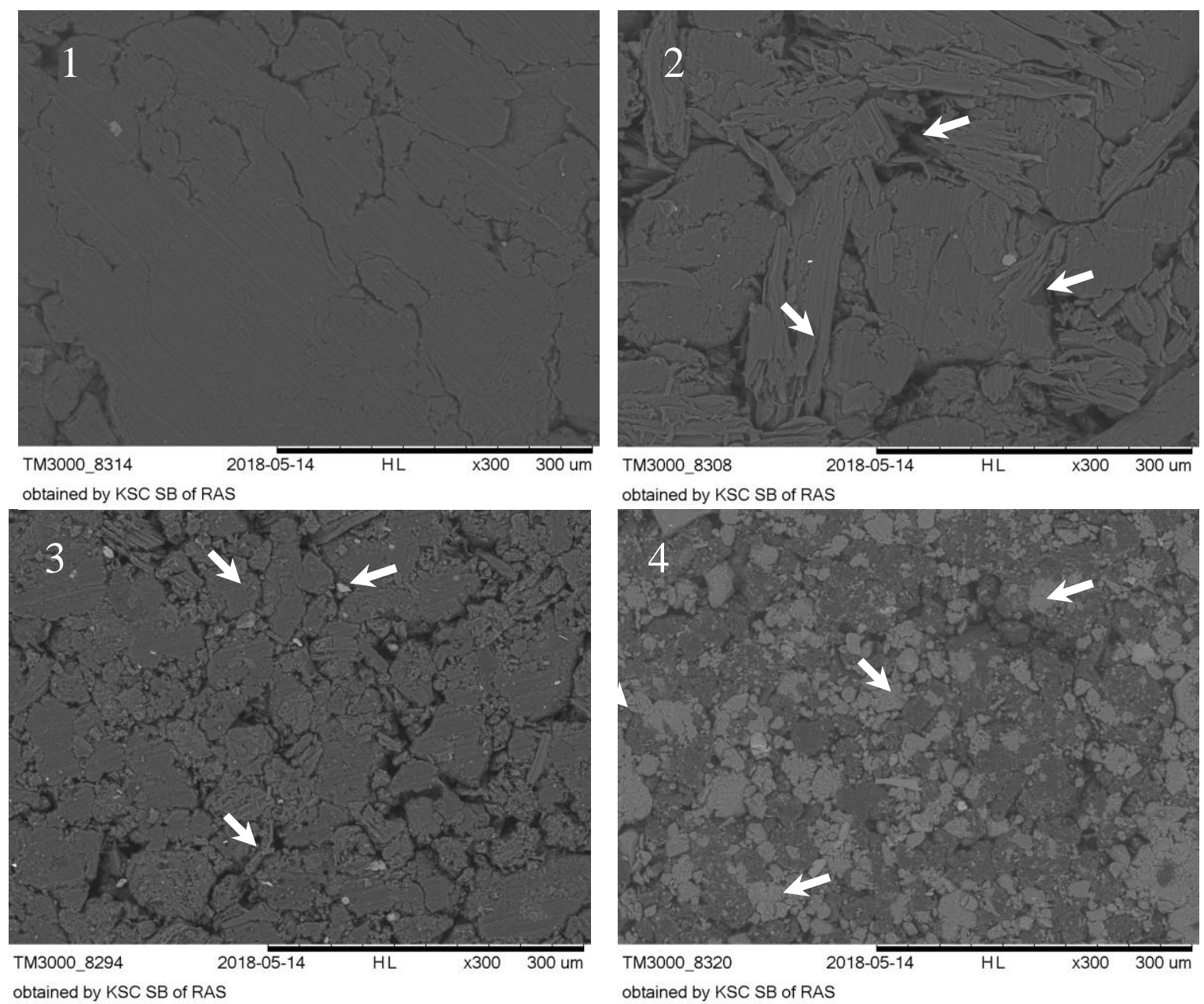

Fig. 4. SEM images of pressed pellets $(\mathrm{P}(3 \mathrm{HB}) /$ filler $=70 / 30): 1-\mathrm{P}(3 \mathrm{HB})$; 2 $\mathrm{P}(3 \mathrm{HB}) /$ wood flour; 3- $\mathrm{P}(3 \mathrm{HB}) /$ peat; 4-P(3HB)/clay

The filling of the hydrophobic $\mathrm{P}(3 \mathrm{HB})$ with the hydrophilic natural materials considerably enhanced the water absorption capacity of the blends (Fig. 6).
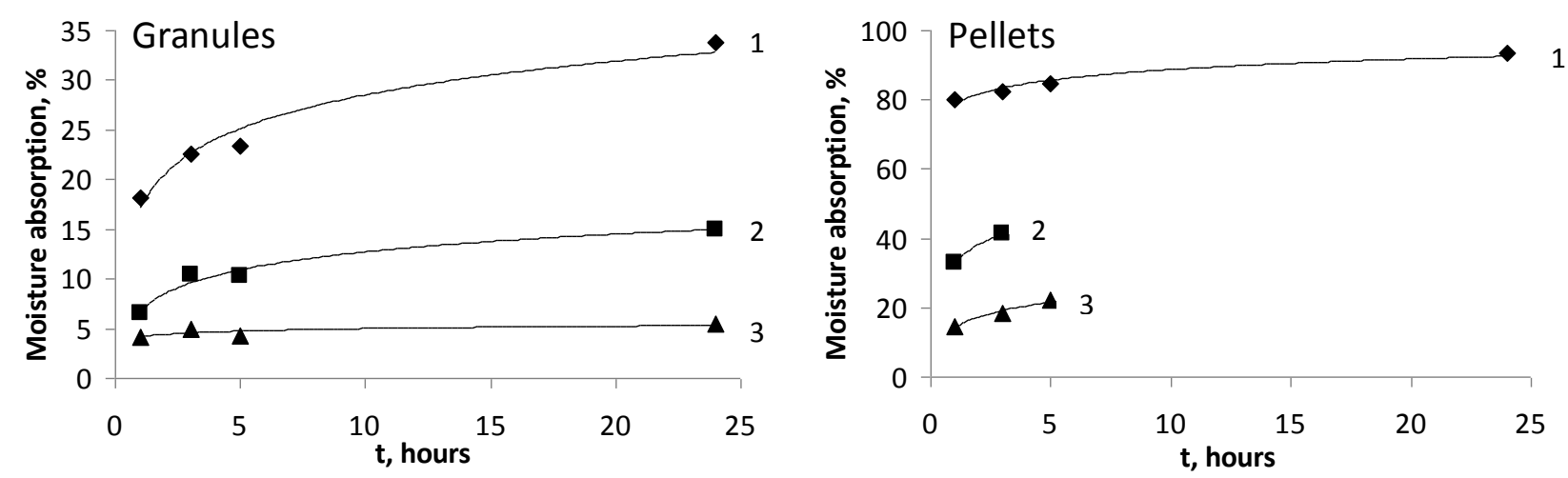

Fig. 6. Moisture absorption: $1-\mathrm{P}(3 \mathrm{HB}) /$ wood flour; $2-\mathrm{P}(3 \mathrm{HB}) /$ peat; $3-\mathrm{P}(3 \mathrm{HB}) /$ clay.

Pellets showed higher moisture absorption. The moisture absorption by the $\mathrm{P}(3 \mathrm{HB}) /$ wood flour pellets reached $93.5 \%$ in $24 \mathrm{~h}$. The moisture absorption by $\mathrm{P}(3 \mathrm{HB}) /$ peat and $\mathrm{P}(3 \mathrm{HB}) / \mathrm{clay}$ pellets measured after the first 3 and $5 \mathrm{~h}$ was 41.3 and $22.9 \%$, respectively; then, water-filled pellets became deformed. Granules absorbed less moisture than pellets. $\mathrm{P}(3 \mathrm{HB}) /$ wood flour granules absorbed the largest amount of water $-33.8 \%$ for $24 \mathrm{~h}$, while moisture absorption by $\mathrm{P}(3 \mathrm{HB}) /$ clay granules was the lowest $-5.4 \%$ for $24 \mathrm{~h}$. In contrast to pellets, granules retained 
their shape. The reason for destruction of pellets was that they had been prepared from the mechanically mixed blend, in which polymer and filler particles were located next to each other. Upon contact with water, the more hydrophilic filler absorbed moisture and swelled. That swelling damaged the polymer matrix and, subsequently, the pellet was destroyed. During preparation of granules, polymer particles encapsulated filler particles, thus reducing the hydrophilicity of the blend and moisture absorption of the granules.

\section{IR spectrophotometry}

The blends were characterized using DSC, X-ray examination, and IR spectroscopy. IR spectra of the blends are shown in Figure 5.
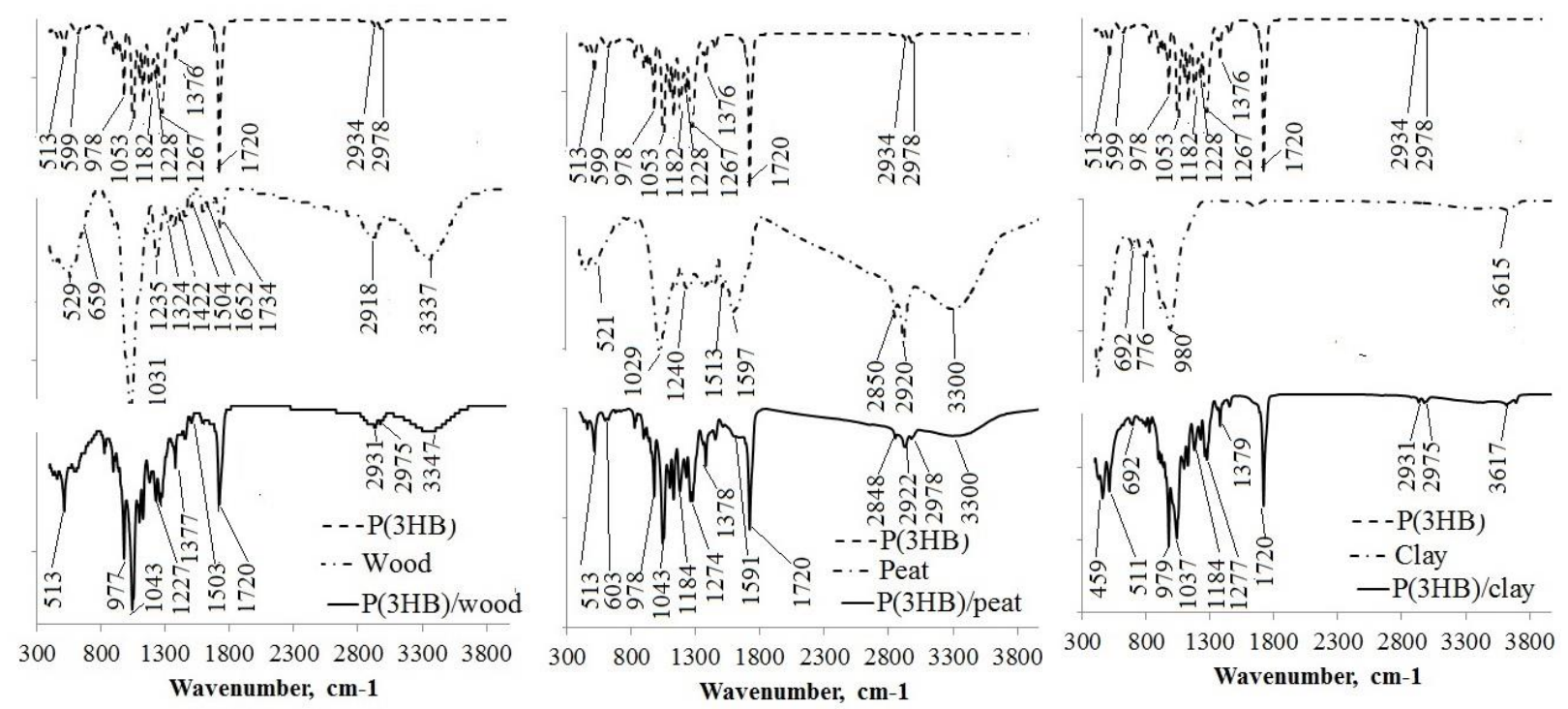

Fig. 5 FT-IR spectra of the blends $(\mathrm{P}(3 \mathrm{HB}) /$ filler $=70 / 30): 1-\mathrm{P}(3 \mathrm{HB}) /$ wood flour; $2-$ $\mathrm{P}(3 \mathrm{HB}) /$ peat; $3-\mathrm{P}(3 \mathrm{HB}) /$ clay.

IR spectrometry showed that characteristic absorption bands of initial components were separately retained in all blends: for $\mathrm{P}(3 \mathrm{HB})$ those were $\mathrm{CH}, \mathrm{CH}_{2}, \mathrm{CH}_{3}, \mathrm{C}-\mathrm{OH}$, and $\mathrm{COOH}$ groups; for peat - the additional and characteristic $\mathrm{S}-\mathrm{S}-, \mathrm{C}=\mathrm{C}, \mathrm{C}=\mathrm{N}, \mathrm{N}-\mathrm{H}$ groups; for clay $-\mathrm{Si}$ $\mathrm{O}-\mathrm{Si}(\mathrm{AL})$ and $\mathrm{Fe}-\mathrm{O}$ in $\mathrm{a}-\mathrm{Fe}_{2} \mathrm{O}_{3}$; for birch wood flour - $-\mathrm{C}-\mathrm{O}-;-\mathrm{C}-\mathrm{O}-\mathrm{C}-$. In the spectra of the blends, absorption bands were either separate bands or coinciding peaks, some of them transformed. An insignificant difference in numbers was within the limits of spectral error -4 $\mathrm{cm}^{-1}$ (accumulation of 256 scans) and could result from increased moisture content of some of the samples. No new significant absorption bands were revealed in the blends, suggesting that no new chemical bonds were formed and that the blends prepared by the techniques employed in this study were physical mixtures.

\section{$X$-Ray analysis}

Blending of $\mathrm{P}(3 \mathrm{HB})$ with the fillers changed the properties of the polymer. The blends became progressively amorphous as the percentage of the fillers was increased $(10,30$, and $50 \%$ fillings of the polymer with natural materials were tested). The degree of crystallinity of $\mathrm{P}(3 \mathrm{HB})$ was decreased more noticeably in the blends with peat and wood flour (materials with low $\mathrm{C}_{\mathrm{x}}$ ). The $\mathrm{C}_{\mathrm{x}}$ of the $\mathrm{P}(3 \mathrm{HB}) /$ peat and $\mathrm{P}(3 \mathrm{HB}) /$ wood flour blends with $30 \%$ filler decreased to 47 and $48 \%$, respectively; the $C_{x}$ of the blends with $50 \%$ of the same fillers decreased to 42 and $44 \%$, respectively. That is, amorphous phase prevailed in these blends (Fig. 1 b, Table 1). In the $\mathrm{P}(3 \mathrm{HB}) /$ clay blends, the crystalline phase prevailed at all levels of filling of the polymer with clay; the $\mathrm{C}_{\mathrm{x}}$ was no less than $56 \%$. Changes in the crystallization kinetics of the polymer in the blends were associated with the rather high percentages of fillers (30 and 50\%). This must have decreased the free volume necessary for nucleation of spherulites to occur, preventing the development of the crystalline phase and, thus, reducing it.

\section{DSC analysis}


Thermograms of the blends were taken in a wide range of temperatures including boundaries of melting and thermal decomposition (Fig. 2). DSC was used as one of the most informative methods for determining thermal properties of polymers and polymer-based blends, as melting behavior of components of the blend provides evidence of the degree of miscibility and interactions of the components. Our results showed that the fillers did not significantly affect the temperatures of melting and thermal decomposition of $\mathrm{P}(3 \mathrm{HB})$ but considerably decreased enthalpy of melting (Table 1). Compared to enthalpy of melting of $\mathrm{P}(3 \mathrm{HB})(89.3 \mathrm{~J} / \mathrm{g})$, the enthalpy of melting of the blends containing $30 \%$ clay, peat, and wood flour decreased to 38.5 , 59.7 , and $51.3 \mathrm{~J} / \mathrm{g}$ and to $29.8,48.7$, and $45.4^{\circ} \mathrm{C}$ for the blends with $50 \%$ of the fillers. Melting temperature was not affected by fillers, as it is largely the property of the polymer matrix. The components of the blend (polymer and filler) are mixed mechanically, the chemical structure of the polymer remains unchanged, and, thus, the filler does not produce any effect on the melting temperature. The peak of degradation for the $\mathrm{P}(3 \mathrm{HB}) /$ clay and $\mathrm{P}(3 \mathrm{HB}) /$ peat blends with $30 \%$ of the filler was at 283 and $292^{\circ} \mathrm{C}$, i.e. the temperatures insignificantly different from the degradation temperature of pure polymer $\left(287^{\circ} \mathrm{C}\right)$; for the blends containing $50 \%$ of the fillers, the peaks of degradation were at 276 and $290^{\circ} \mathrm{C}$, respectively. The lower degradation temperature of the blend containing $50 \%$ clay can be explained using dispersion concept. The increase in the amount of clay in the blend impaired the dispersion of the filler in the polymer matrix and clay particles could agglomerate. This secondary structure in the polymer matrix could accumulate heat from external sources and, eventually, trigger a more rapid onset of decomposition.

For the $\mathrm{P}(3 \mathrm{HB}) /$ peat blend, thermograms showed the onset of thermal decomposition at $225^{\circ} \mathrm{C}$, in contrast to pure polymer $\left(270^{\circ} \mathrm{C}\right)$ and the $\mathrm{P}(3 \mathrm{HB}) /$ clay blend $\left(272^{\circ} \mathrm{C}\right)(\mathrm{Fig}$. $2 \mathrm{~b})$. For the $\mathrm{P}(3 \mathrm{HB}) /$ wood flour blend, the degradation peak was observed at $273^{\circ} \mathrm{C}$ (at a temperature $14^{\circ} \mathrm{C}$ lower than the temperature for pure polymer), and the onset of decomposition occurred at $259^{\circ} \mathrm{C}$. A possible reason for the lower temperatures for decomposition of the $\mathrm{P}(3 \mathrm{HB}) /$ wood flour blend could be accumulation of wood flour decomposition products in the melt, which could catalyze destruction of the polymer matrix. For the $\mathrm{P}(3 \mathrm{HB}) /$ clay and $\mathrm{P}(3 \mathrm{HB}) /$ peat blends, no appreciable change in the temperature of crystallization was noted. By contrast, for the $\mathrm{P}(3 \mathrm{HB}) /$ wood flour blend, the temperature of crystallization was insignificantly lower $\left(106^{\circ} \mathrm{C}\right)$. Wood flour particles could serve as defect centers and prevent polymer chains from folding, producing smaller crystals and causing the temperature of crystallization to decrease. In conditions of the thermal analysis, glass transition temperature was not registered. This fact was noted for many times previously for $\mathrm{P}(3 \mathrm{HB})$ samples we synthesized [30,31]. Because glass transition process is defined by the amorphous phase, high $\mathrm{P}(3 \mathrm{HB})$ crystallinity may complicate detection of this parameter.

\subsection{A physical/mechanical study}

Analysis of physical/mechanical properties of the pellets prepared from initial materials and blends is shown in Figure 6 (granules had very low values and, therefore, they were not studied). Young's moduli of the pellets prepared from initial materials varied considerably, and the highest value was obtained for $\mathrm{P}(3 \mathrm{HB})$ pellets $(350 \mathrm{MPa})$. Young's moduli of all fillers were lower: $2890 \mathrm{MPa}$ for wood flour pellets, $138 \mathrm{MPa}$ for peat pellets, and $50 \mathrm{MPa}$ for clay pellets. Under downward force applied to pellets prepared from blends, compressive strength of the pellets consistently decreased as the percentage of the filler increased. $\mathrm{P}(3 \mathrm{HB}) /$ wood flour pellets showed the highest resistance: Young's moduli of the pellets with $30 \%$ and $50 \%$ of the filler reached 310 and $276 \mathrm{MPa}$, respectively. The $\mathrm{P}(3 \mathrm{HB}) /$ peat and $\mathrm{P}(3 \mathrm{HB}) /$ clay pellets with $50 \%$ of the fillers showed the lowest values of Young's modulus: 150 and $76 \mathrm{MPa}$, respectively. The reason for that could be amorphization of the blends: the amount of the polymer, in which crystalline phase prevailed (75\%), decreased and the amount of the filler, with the prevailing amorphous phase, increased. 

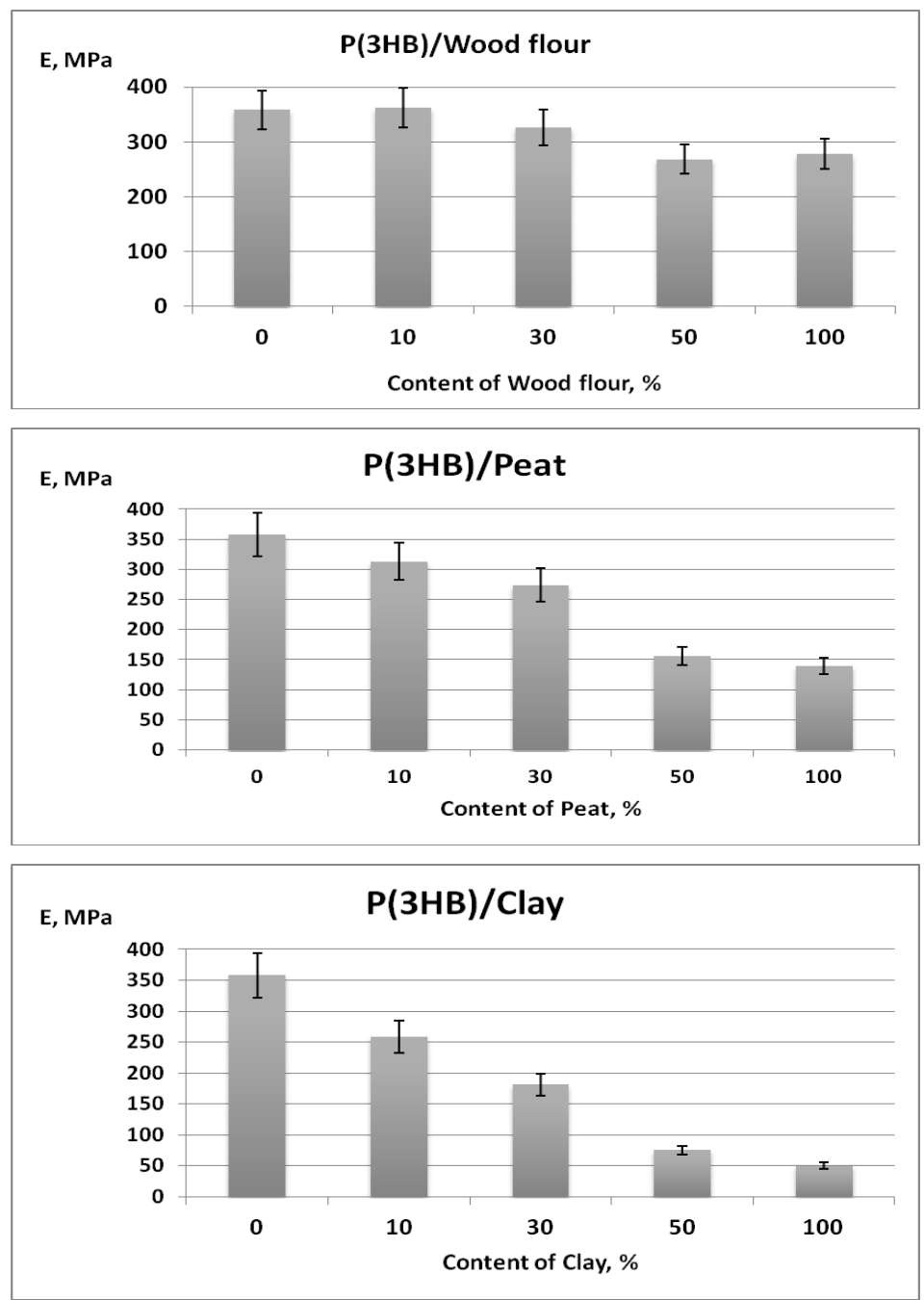

Fig. 6. Young's modulus of the pressed pellets prepared from blends of $\mathrm{P}(3 \mathrm{HB})$ and fillers mixed in different proportions

3.4. Degradation of pellets and granules prepared from blends in soil

As the blends prepared and tested in this study can be considered as potential carriers for pesticides and fertilizers for soil application and as materials for fabricating degradable packaging and other goods, it is important to study their degradation in soil. Figure 7 is a photograph of pellets and granules degraded for $35 \mathrm{~d}$ in agro-transformed (field) soil; Figure 8 is their SEM photographs; Figure 9 shows their degradation kinetics. 


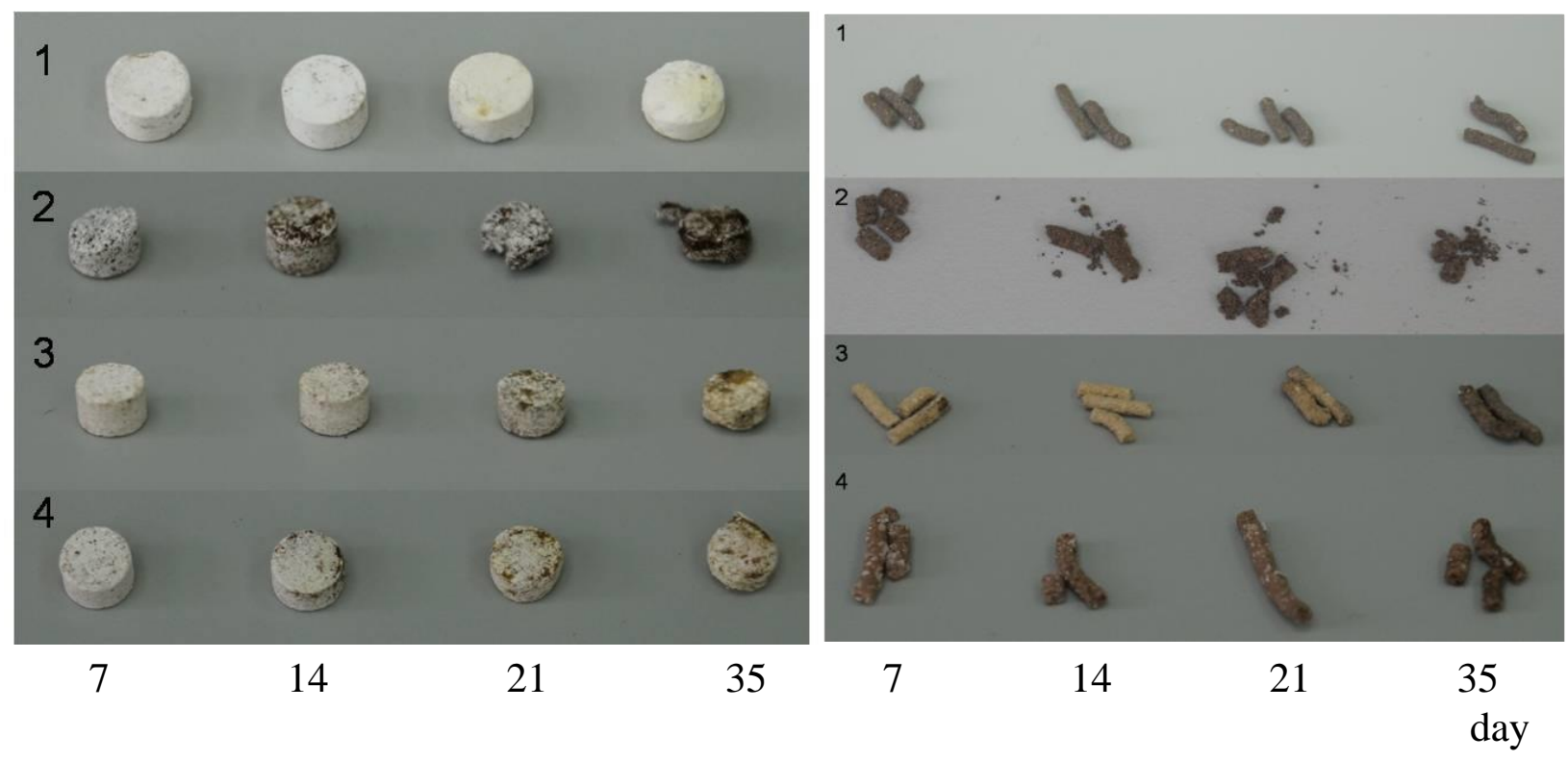

Fig. 7. Photographs of pellets and granules at different time points of their degradation in soil: 1 - $\mathrm{P}(3 \mathrm{HB}), 2-\mathrm{P}(3 \mathrm{HB}) /$ peat, $3-\mathrm{P}(3 \mathrm{HB}) /$ wood flour, $4-\mathrm{P}(3 \mathrm{HB}) /$ clay
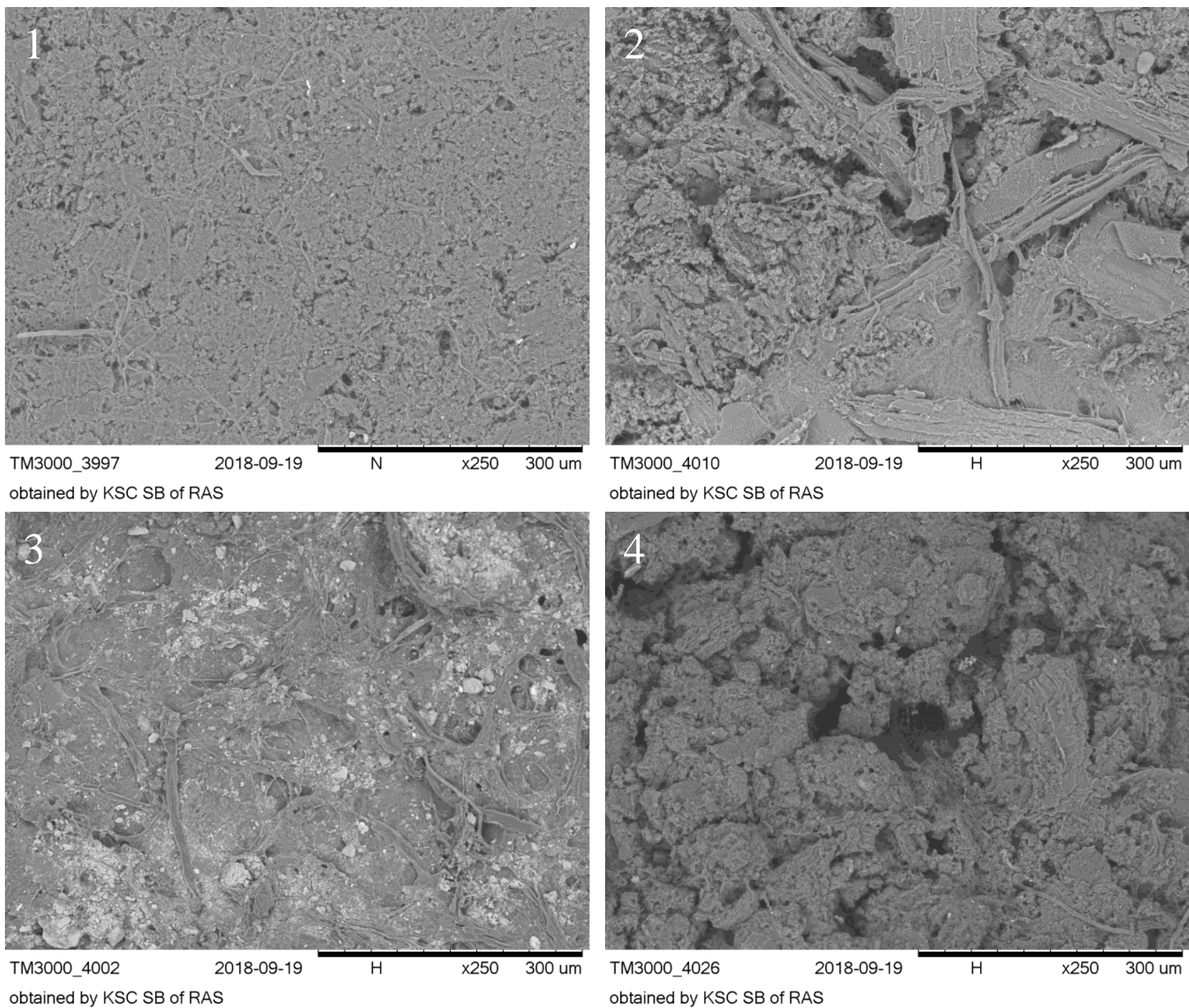

obtained by KSC SB of RAS

obtained by KSC SB of RAS

Fig. 8. SEM images of pressed pellets $(\mathrm{P}(3 \mathrm{HB}) /$ filler $=70 / 30)$ at different time points of their degradation in soil: 1-P(3HB); 2- $\mathrm{P}(3 \mathrm{HB}) /$ wood flour; 3- $\mathrm{P}(3 \mathrm{HB}) /$ peat; 4-P(3HB $) /$ clay 

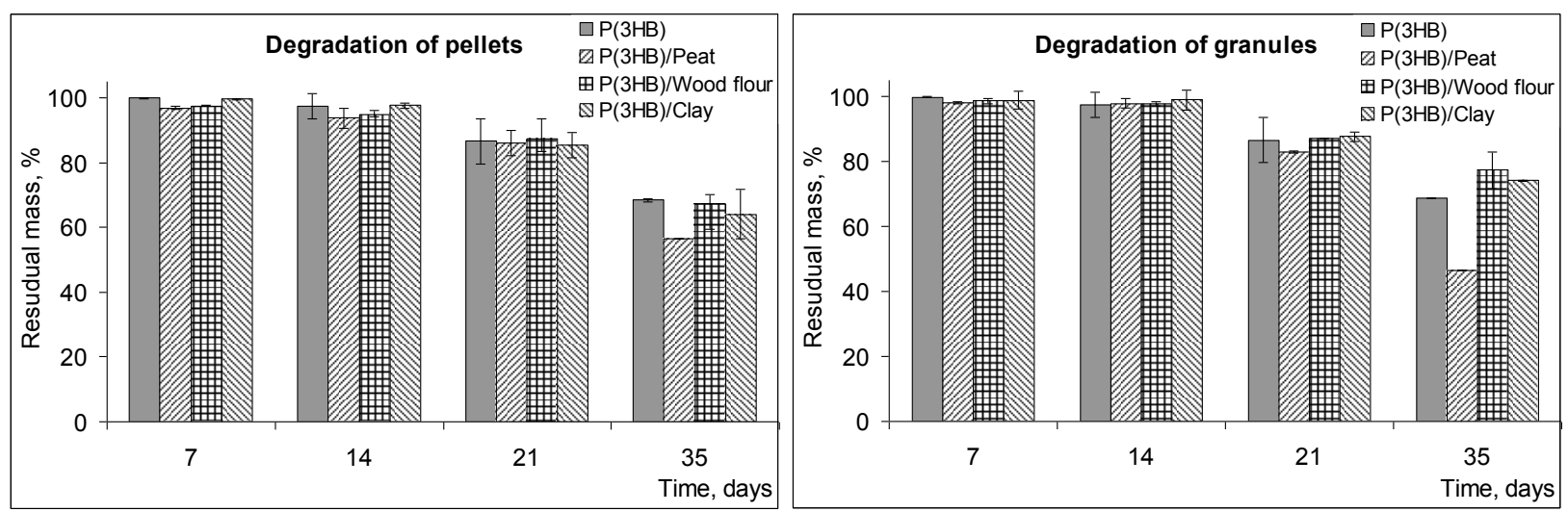

Fig. 9. Kinetics of degradation of experimental pellets and granules in soil

Pellets and granules of all compositions were degraded at high rates after 3 weeks of incubation in soil (Fig. 9 a). By the end of the experiment, residual mass of the pellets had decreased to $68 \%$ for $\mathrm{P}(3 \mathrm{HB}), 56.4 \%$ for $\mathrm{P}(3 \mathrm{HB}) /$ peat, $67 \%$ for $\mathrm{P}(3 \mathrm{HB}) /$ wood flour, and $64 \%$ for $\mathrm{P}(3 \mathrm{HB}) /$ clay. Granules exhibited a similar mass loss (Fig. 9 b); high biodegradation rates were also observed after 3 weeks of incubation in soil. At the end of the experiment, residual mass of the granules of $\mathrm{P}(3 \mathrm{HB})$ was $68.4 \%, \mathrm{P}(3 \mathrm{HB}) /$ peat $46.4 \%, \mathrm{P}(3 \mathrm{HB}) /$ wood flour $77 \%$, and $\mathrm{P}(3 \mathrm{HB}) /$ clay $74 \%$. Both pellets and granules made from the $\mathrm{P}(3 \mathrm{HB}) /$ peat blend showed a somewhat more considerable mass loss. However, all pellets and granules during the experiment showed comparable mass loss, which was mainly caused by polymer degradation. The mass loss of the specimens except $\mathrm{P}(3 \mathrm{HB}) /$ peat blends was about $30-40 \%$ for $35 \mathrm{~d}$, suggesting slow destruction of all products in soil.

\subsection{Discussion}

A relatively new line of research is filling of polyhydroxyalkanoates with natural materials to improve properties of the polymers and reduce their cost, in order to widen the range and increase the scale of their applications. This is particularly important for the large-scale use of PHAs in technical areas and agriculture.

The fillers of $\mathrm{P}(3 \mathrm{HB})$ used in the present study were clay, birch wood flour, and peat. These materials were chosen for the following reasons. Clay is a common and relatively cheap natural material; it has attracted a good deal of attention among researchers as material for nanocomposites. Wood flour, as well as other wood waste, is produced in great quantities everywhere, and, thus, this is another potentially useful material for manufacturing hybrids. Peat is relatively safe for the environment and it is abundant; burial of peat in soil as a component of biodegradable packaging or carrier of fertilizers or other chemicals is safe for soil biota and even improves its structure.

The literature search revealed few studies that describe results of using natural materials, including waste, as fillers. Angelini et al. [26] reported using a lignocellulosic biomass (LC), biowaste from the second generation bioethanol production process as a filler of $\mathrm{P}(3 \mathrm{HB})$. LC was processed in order to isolate its main components: holocellulose $(\mathrm{HC})$ and acid-insoluble lignin (IL). LC and its derivatives were introduced as fillers at $30 \mathrm{wt} \%$ in $\mathrm{P}(3 \mathrm{HB})$. The blends were prepared by a solvent-assisted method. The addition of IL to $\mathrm{P}(3 \mathrm{HB})$ affected its rheological properties, significantly enhancing melt stability due to the formation of a percolated filler network within the matrix. The DSC analysis showed that LC and HC promoted the polymer melt crystallization, potentially enabling control of physical aging of $\mathrm{P}(3 \mathrm{HB})$. To sum up, that study provided an insight into the effect of a lignocellulosic biowaste and its derivatives on the properties of a naturally occurring, biodegradable polyester.

Other studies [27-29] discuss properties and potential uses of wood waste and PHA to fabricate wood particle boards. The studies proved that PHAs could serve as nontoxic binding 
material instead of toxic formaldehyde resins. Addition of 15 to $30 \%$ PHA to wood flour and chips enhanced their mechanical strength: modulus of rupture rose from 5.27 to $6.58 \mathrm{MPa}$ and internal bond strength from 0.18 to $0.22 \mathrm{MPa}$. Water resistance of the material increased, too: water absorption decreased from 115.48 to $85.62 \%$. The authors concluded that such mixes were promising materials for construction industry. A similar conclusion was reached in another study [35], in which PHAs were tested as adhesive materials, and the particleboards made from oil palm trunks with addition of PHA were stronger than the boards fabricated without adding PHA.

Studies by Bakri et al. [36,37] describe using acacia wood and discuss the positive ecoeconomic aspect of using wood waste in combination with degradable polymers, PHAs. The authors proposed producing stronger and naturally degradable hybrids based on wood waste and thermoplastic PHAs and polylactides.

Studies by Maiti et al. [20,21] reported preparation of $\mathrm{P}(3 \mathrm{HB}) /$ clay composites by melt extrusion. Clay was pre-modified with octadecyl ammonium. Well-ordered intercalated clay nanocomposites with decreased d-spacing were produced. Mechanical tests showed that the fluoromicas led to higher enhancement than montmorillonite. Bittmann et al. [38] studied the effects of clay fillers on surface modification, dispersive state, heat and dynamic mechanical properties of $\mathrm{P}(3 \mathrm{HB}-\mathrm{co}-3 \mathrm{HV})$ copolymers. Montmorillonite and bentonite were used as clay component. In a study by Lim et al. [22], $\mathrm{P}(3 \mathrm{HB})$ composites with clay fillers were prepared by suspending organomodified montmorillonite (OMMT, a commercial preparation) in a polymer solution; the authors noted intercalation of polymer chains into layered structures of clay and enhanced thermal stability of the composite compared to the initial $\mathrm{P}(3 \mathrm{HB})$. The study by Torres-Giner et al. [23] deals with grafting of sepiolite nanoclay onto poly(3-hydroxybutyrateco-4-hydroxybutyrate) biopolymer by melt compounding. The newly formed sepiolite-grafted $\mathrm{P}(3 \mathrm{HB}-\mathrm{co}-4 \mathrm{HB})$ (sepiolite- $g-\mathrm{P}(3 \mathrm{HB}-c o-4 \mathrm{HB})$ ) nanocomposite showed higher thermal, thermomechanical, and mechanical performance than the equivalent ungrafted nanocomposite. Melt grafting of sepiolite at different weight contents (1,3, and $5 \mathrm{wt} . \%)$ increased the thermal stability and stiffness of $\mathrm{P}(3 \mathrm{HB}-\mathrm{co}-4 \mathrm{HB})$ without impairing its ductility and toughness.

In the present study, $\mathrm{P}(3 \mathrm{HB})$ was blended with three natural materials, the blends were used to prepare pellets and granules, and their properties were studied.

IR spectroscopy was used to reveal possible structural differences between the blends. The IR spectra of the initial $\mathrm{P}(3 \mathrm{HB})$, each of the three natural materials, and their blends were taken in the 400-4000 $\mathrm{cm}^{-1}$ range. The spectra of all blends retained characteristic absorption bands of the initial components: for $\mathrm{P}(3 \mathrm{HB})$ those were $\mathrm{CH}, \mathrm{CH}_{2}, \mathrm{CH}_{3}, \mathrm{C}-\mathrm{OH}$, and $\mathrm{COOH}$ groups; for peat - the additional and characteristic $\mathrm{S}-\mathrm{S}-, \mathrm{C}=\mathrm{C}, \mathrm{C}=\mathrm{N}, \mathrm{N}-\mathrm{H}$ groups; for clay $-\mathrm{Si}$ $\mathrm{O}-\mathrm{Si}(\mathrm{Al})$ and $\mathrm{Fe}-\mathrm{O}$ in $\mathrm{a}-\mathrm{Fe}_{2} \mathrm{O}_{3}$; for birch wood flour - -C-O-;-C-O-C-. No new absorption bands were visible in the spectra of the blends, suggesting that no new chemical bonds were formed and the blends prepared by the methods employed in this study, without using chemical reagents and heating, were physical mixtures. However, in the study by Torres-Giner et al. [23], in which composites of sepiolite nanoclay and $\mathrm{P}(3 \mathrm{HB}-\mathrm{co}-4 \mathrm{HB})$ copolymer were produced by melt compounding, during thermal extrusion, the reactive coupling agent successfully established strong chemical "bridges" between the biopolymer and sepiolite by $\mathrm{Si}-\mathrm{O}-\mathrm{C}$ bonds. As a result, it generated a new hybrid nanostructure, i.e., a sepiolite-grafted $\mathrm{P}(3 \mathrm{HB}-\mathrm{co}-4 \mathrm{HB})$ (sepiolite$\mathrm{g}-\mathrm{P}(3 \mathrm{HB}-\mathrm{co}-4 \mathrm{HB}))$ nanocomposite. Thus, the technique of processing of the PHA/filler blend is a more important factor determining the type of the blend than the chemical composition of the material.

A scanning electron microscope equipped with a system for X-ray spectrometry was used to perform elemental analysis of the initial materials and their blends, which showed considerable differences between the samples. The $\mathrm{P}(3 \mathrm{HB}) /$ wood flour blend contained not only carbon and oxygen but also $\mathrm{Si}, \mathrm{Al}, \mathrm{Fe}, \mathrm{Ca}$, and $\mathrm{S} ; \mathrm{P}(3 \mathrm{HB}) /$ peat blends additionally contained $\mathrm{Mg}$ and $\mathrm{K}$. The elemental composition of $\mathrm{P}(3 \mathrm{HB}) /$ clay blends was the most diverse. They contained 11 elements: in addition to the elements mentioned above, analysis detected $\mathrm{Na}, \mathrm{Ti}$, and $\mathrm{Mn}$. 
Materials used as fillers for $\mathrm{P}(3 \mathrm{HB})$ had different structure and properties and, thus, produced different effects on the morphology and properties of the blends. First of all, the initially hydrophobic polymer blended with hydrophilic fillers acquired the ability to sorb water. Pellets prepared from $\mathrm{P}(3 \mathrm{HB}) /$ wood flour blends had higher water absorption capacity than the products of $\mathrm{P}(3 \mathrm{HB}) /$ peat and $\mathrm{P}(3 \mathrm{HB}) /$ clay blends. As the amounts of fillers in the blends were increased, the degree of crystallinity of the polymer decreased, especially in the $\mathrm{P}(3 \mathrm{HB})$ blends with wood flour and peat, whose $C_{x}$ values were initially the lowest. These blends mainly consisted of the amorphous phase. These results are in good agreement with the data reported in a study by Thiré et al. [39], suggesting that attapulgite clay decreased the degree of crystallinity of $\mathrm{P}(3 \mathrm{HB}-\mathrm{co}-3 \mathrm{HV})$; the authors also noted an insignificant decrease in the temperature of crystallization and the melting point of the blend with an increase in clay concentration from 1 to $5 \%$.

The study of thermal properties of the blends did not show any significant influence of the fillers on the temperatures of melting and thermal decomposition and the position of the $\mathrm{T}_{\text {melt }}$ and $\mathrm{T}_{\text {degr }}$ peaks in thermograms. However, the onset of thermal decomposition of the blends was shifted to the left relative to the initial $\mathrm{P}(3 \mathrm{HB})$. The enthalpy of melting of the blends was significantly decreased (by a factor of 1.5-2.2). It is difficult to compare results obtained in this study with literature data because of data scarcity and different techniques used to process blends into products. Results of our study, however, are consistent with the data reported in a study by Angelini et al. [26], in which unprocessed wood flour was used as a filler, and thermograms showed an earlier onset of degradation of the blend compared to pure $\mathrm{P}(3 \mathrm{HB})$. The temperature properties of the $\mathrm{P}(3 \mathrm{HB}) /$ clay blends obtained in this study are in good agreement with the data reported in a study by Lim et al. (2003), in which $\mathrm{P}(3 \mathrm{HB}) /$ clay blends were prepared by dissolving the components together and the subsequent removal of the solvent. The authors of that study described formation of intercalated structures, but did not reveal any effect of the filler on $\mathrm{P}(3 \mathrm{HB})$ properties, which was confirmed by IR spectra that showed the presence of two different phases.

We did not find any available studies of $\mathrm{P}(3 \mathrm{HB})$ blends with peat. Peat was used as a filler in composites with polylactide and polypropylene [40] and was found to affect crystallization of polylactide. Tensile strength of peat composites was lower than that of cellulose composites, but peat composites had higher impact strength. The authors concluded that polymer/peat composites were promising materials for agriculture.

The study of physicochemical properties of $\mathrm{P}(3 \mathrm{HB})$ blends with the three natural materials did not reveal any dramatic impairment of the properties of the polymer. However, Young's moduli of all blends decreased as the amount of the filler in the blend increased. The most significant decrease in Young's modulus was observed in the $\mathrm{P}(3 \mathrm{HB}) /$ peat and $\mathrm{P}(3 \mathrm{HB}) /$ clay blends containing $50 \%$ of the filler: the parameter dropped to 150 and $76 \mathrm{MPa}$, respectively, compared to Young's modulus of the initial polymer of approximately $360 \mathrm{MPa}$. These results differ from the data reported in a study by Bensalah et al. [34], which addressed the effect of clay on thermal and mechanical properties of polypropylene (PP) - a polymer whose basic properties are similar to those of $\mathrm{P}(3 \mathrm{HB})$. The authors of that study showed that clay used as a filler enhanced commercial properties of PP, increasing Young's modulus. Just like in our study, the addition of different amounts of clay (between 5 and 20\%) to PP did not affect $\mathrm{T}_{\text {melt }}$, insignificantly decreased crystallinity, and considerably decreased enthalpy.

As $\mathrm{P}(3 \mathrm{HB})$ blends can be considered as potential carriers for pesticides and fertilizers for soil application and as materials for fabricating degradable packaging and other goods, it is important to study their degradation behavior in soil. Degradation of $\mathrm{P}(3 \mathrm{HB})$ blends with natural materials was first investigated in this study, showing that the mass loss of the blends over 35 days of incubation in soil varied between 30 and 50\% of the initial mass of the products, depending on the type of the filler.

\section{Conclusions}


Natural materials - clay, birch wood flour, and peat - were used as fillers for degradable poly-3-hydroxybutyrate. All materials were ground into powder with particle size of $200 \mu \mathrm{m}$. The $\mathrm{P}(3 \mathrm{HB}) /$ filler dry powder and wet paste (40\% moisture content in ethanol) were coldpressed to produce pellets and granules. All initial materials and blends were investigated using IR spectroscopy, DSC, X-ray analysis, electron microscopy with microanalysis and X-ray spectrometry. Analysis of IR spectra showed that no chemical bonds were established between the polymer and fillers and that the blends were physical mixtures. Their temperature characteristics and degrees of crystallinity were lower than those of $\mathrm{P}(3 \mathrm{HB})$, suggesting different crystallization kinetics of the blends. The hydrophobic $\mathrm{P}(3 \mathrm{HB})$ filled with the natural materials acquired the ability to sorb moisture; Young's modulus of the blends was lower than that of $\mathrm{P}(3 \mathrm{HB})$. Degradation behavior of pellets and granules prepared from $\mathrm{P}(3 \mathrm{HB}) /$ filler blends in soil was similar to degradation behavior of pure polymer. The mass loss of all pellets and granules over 35 days of incubation in soil varied between 30 and $50 \%$ of the initial mass of the products, depending on the type of the filler. Thus, the blends prepared and tested in this study can be used to fabricate degradable packaging, greenhouse accessories, and delivery systems for fertilizers and pesticides.

\section{Acknowledgements}

This study was financially supported by Project "Agropreparations of the new generation: a strategy of construction and realization" (Agreement No 074-02-2018-328) in accordance with Resolution No 220 of the Government of the Russian Federation of April 9, 2010, "On measures designed to attract leading scientists to the Russian institutions of higher learning”.

Surface of the samples was investigated using a scanning electron microscope Hitachi TM-3000 in the Center of the common use of Krasnoyarsk Scientific Center of Siberian Branch of Russian Academy of Sciences.

There are no conflicts of interest to declare.

\section{References}

[1] S. Tanabe, M. Watanabe, T.B. Minh, et al, PCDDs, PCDFs, and coplanar PCBs in albatross from the North Pacific and Southern Oceans: levels, patterns, and toxicological implications, Environ Sci Technol. 38 (2004) 403-413. https://doi.org/10.1021/es034966x.

[2] A.K. Urbanek, W. Rymowicz, A.M. Mirończuk. Degradation of plastics and plasticdegrading bacteria in cold marine habitats, Applied Microbiology and Biotechnology. 102 (2018) 7669-7678. https://doi.org/10.1007/s00253-018-9195-y.

[3] A. Qaiss, R. Bouhf, H. Essabir, Characterization and use of coir, almond, apricot, argan, shell, and wood as reinforcement in the polymeric matrix in order to valorize these products. In: K. Hakeem, M. Jawaid, Y. Alothman O. (eds), Agricultural Biomass Based Potential Materials, Springer, Cham, 2015, p. 305-339.

[4] G.-Q. Chen, Plastics from bacteria: natural functions and applications, Microbiology Monographs, Springer-Verlag, Berlin, Heidelberg, 2010.

[5] B. Laycock, H. Peter, S. Pratt, A. Werker, P. Lant, The chemomechanical properties of microbial polyhydroxyalkanoate, Prog. Polym. Sci. 38 (2013) 536-583. https://doi.org/10.1016/j.progpolymsci.2012.06.003.

[6] T.G. Volova, E.I. Shishatskaya, A.J. Sinskey, Degradable Polymers: Production, Properties, Applications, Nova Science Pub. Inc., New York, 2013.

[7] T.G. Volova, Yu.S. Vinnik, E.I. Shishatskaya, N.M. Markelova, G.E. Zaikov, Natural-Based Polymers for Biomedical Applications, Canada: Appl.Acad.Press, 2017.

[8] M. Koller, L. Maršálek, M.M. de Sousa Dias, G. Braunegg, Producing microbial polyhydroxyalkanoate (PHA) biopolyesters in a sustainable manner, New Biotechnol. 37 (2017) 24-38. https://doi.org/10.1016/j.nbt.2016.05.001. 
[9] E. Bugnicourt, P. Cinelli, A. Lazzeri, V. Alvarez, Polyhydroxyalkanoate (PHA): Review of synthesis, characteristics, processing and potential applications in packaging, eXPRESS Polymer Letters. 8 (2014) 791-808. https://doi.org/10.3144/expresspolymlett.2014.82.

[10] A.F. Hernández, T. Parrón, A.M. Tsatsakis, et al, Toxic effects of pesticide mixtures at a molecular level: their relevance to human health, Toxicology. 37 (2013) 136-145. https://doi.org/10.1016/j.tox.2012.06.009.

[11] J. Suave, E.C. Dall'Agnol, A.P.T. Pezzin, M.M. Meier, D.A.K. Silva, Biodegradable Microspheres of Poly(3-hydroxybutyrate)/Poly(e-caprolactone) loaded with Malathion Pesticide: Preparation, Characterization, and In Vitro Controlled Release Testing, Journal of Applied Polymer Science. 117 (2010) 3419-3427. https://doi.org/10.1002/app.32082.

[12] R. Grillo, N.F.S. Melo, R. Lima et al, Characterization of atrazine-loaded biodegradable poly(hydroxybutyrate-co-hydroxyvalerate) microspheres, J. Polym. Environ. 18 (2010) 26-32. https://doi.org/10.1007/s10924-009-0153-8.

[13] R. Grillo, A.E.S. Pereira, N.F.S. Melo, et al, Controlled release system or ametryn using polymer microspheres: preparation, characterization and release kinetics in water, J. Hazard. Mater. 186 (2011) 1645-1651. https://doi.org/10.1016/j.jhazmat.2010.12.044.

[14] F.A. Lobo, C.L. Aguirre, M.S. Silva et al, Poly(hydroxybutyrate-cohydroxyvalerate) microspheres loaded with atrazine herbicide: screening of conditions or preparation, physic-chemical characterization, and in vitro release studies, Polym. Bull. 67 (2011) 479-495. https://doi.org/10.1007/s00289-011-0447-6.

[15] T.G. Volova, N.O. Zhila, O.N. Vinogradova, E.D. Nikolaeva, E.G. Kiselev, A.A. Shumilova, A.M. Shershneva, E.I. Shishatskaya, Constructing herbicide metribuzin sustainedrelease formulations based on the natural polymer poly-3-hydroxybutyrate as a degradable matrix, Journal of Environmental Science and Health, Part B. 51 (2016) 113-125. https://doi.org/10.1080/03601234.2015.1092833.

[16] T.G. Volova, S.V. Prudnikova, A.N. Boyandin, Biodegradable poly-3hydroxybutyrate as a fertilizer carrier, Journal of the Science of Food and Agriculture. 96 (2016) 4183-4193. https://doi.org/10.1002/jsfa.7621.

[17] T.G. Volova, S.V. Prudnikova, N.O Zhila, O.N Vinogradova, A.A Shumilova, E.D. Nikolaeva, E.G. Kiselev, E.I. Shishatskaya, Efficacy of tebuconazole embedded in biodegradable poly-3-hydroxybutyrate to inhibit the development of Fusarium moniliforme in soil

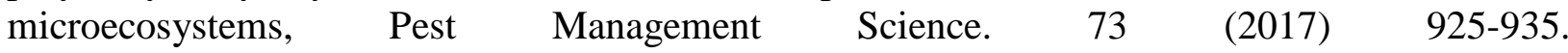
https://doi.org/10.1002/ps.4367.

[18] N. Zhila, A. Murueva, A. Shershneva, E. Shishatskaya, T. Volova, Herbicidal activity of slow-release herbicide formulations in wheat stands infested by weeds, J Env Sci Health, Part B. 52 (2017) 729-735. https://doi.org/10.1080/03601234.2017.1356668.

[19] T.G. Volova, S.V. Prudnikova, N.O Zhila. Fungicidal activity of slow-release $\mathrm{P}(3 \mathrm{HB}) / \mathrm{TEB}$ formulations in wheat plant communities infected by Fusarium moniliforme, Environmental Science and Pollution Research-January. $25 \quad$ (2018) 552-561. https://doi.org/10.1007/s11356-017-0466-4.

[20] P. Maiti, C.A. Batt, E.P. Giannelis, Renewable plastics: synthesis and properties of PHB nanocomposites, Polym. Mater. Sci. Eng. 88 (2003) 58-59.

[21] P. Maiti, E.P. Giannelis, C.A. Batt, Biodegradable polyester/layered silicate nanocomposites, Mater. Res. Soc. 740 (2002). https://doi.org/10.1557/PROC-740-I5.3.

[22] S.T. Lim, Y.H. Hyun, C.H. Lee, H.J. Choi, Preparation and characterization of microbial biodegradable poly(3-hydroxybutyrate)/organoclay nanocomposite, J. Mater. Sci. Lett. 22 (2003) 299-302. https://doi.org/10.1023/A:1022316732412.

[23] S. Torres-Giner, N. Montanes, T. Boronat, L. Quiles-Carrillo, R. Balart, Melt grafting of sepiolite nanoclay onto poly(3-hydroxybutyrate-co-4-hydroxybutyrate) by reactive extrusion with multi-functional epoxy-based styrene-acrylic oligomer, Eur. Polym. J. 84 (2016) 693-707. https://doi.org/10.1016/j.eurpolymj.2016.09.057. 
[24] M.A. Gunning, L.M. Geever, J.A. Killion, J.G. Lyons, C.L. Higginbotha, Mechanical and biodegradation performance of short natural fibre polyhydroxybutyrate $\begin{array}{lllll}\text { composites, } & \text { Polym. } & \text { Testing. } & 32 & \text { (2013) }\end{array}$ https://doi.org/10.1016/j.polymertesting.2013.10.011.

[25] J. de S. Macedo, M.F. Costa, M.I.B. Travares, R.M.S.M. Thirè, Preparation and characterization of composites based on polyhydroxybutyrate and waste powder from coconut fibers processing, Polym. Eng. Sci. 50 (2010) 1466-1475, https://doi.org/10.1002/pen.21669

[26] S. Angelini, P. Cerruti, B. Immirzi, G. Scarinzi, M. Malinconico, Acid-insoluble lignin and holocellulose from a lignocellulosic biowaste: Bio-fillers in poly(3$\begin{array}{lllll}\text { hydroxybutyrate), Eur. } & \text { Polym. } & \text { J. } 76 & \text { (2016) }\end{array}$ https://doi.org/10.1016/j.eurpolymj.2016.01.024.

[27] P. Khunthongkaew, P. Murugan, K. Sudesh, J. Iewkittayakorn, Biosynthesis of polyhydroxyalkanoates using Cupriavidus necator $\mathrm{H} 16$ and its application for particleboard production, Journal of Polymer Research. 25 (2018) 131. https://doi.org/10.1007/s10965-0181521-7.

[28] Jutarut Iewkittayakorn, Piyaporn Khunthongkaew, Wilaiwan Chotigeat, Kumar Sudesh, Effect of Microwave Pretreatment on the Properties of Particleboard Made from Para Rubber Wood Sawdust with the Addition of Polyhydroxyalkanoates, Sains Malaysiana. 46 (2017) 1361-1367. http://www.ukm.my/jsm/english_journals/vol46num9_2.

[29] Luigi-Jules Vandi, Clement Matthew Chan, Alan Werker, Des Richardson, Bronwyn Laycock and Steven Pratt, Wood-PHA Composites: Mapping Opportunities, Polymers. 10 (2018) 751-766. https://doi.org/10.3390/polym10070751.

[30] T.G. Volova, E.G. Kiselev, E.I. Shishatskaya, N.O. Zhila, A.N. Boyandin, D.A. Syrvacheva, O.N. Vinogradova, G.S. Kalacheva, A.D. Vasiliev, I.V. Peterson, Cell growth and accumulation of polyhydroxyalkanoates from $\mathrm{CO}_{2}$ and $\mathrm{H}_{2}$ of a hydrogen-oxidizing bacterium, Cupriavidus eutrophus B-10646, Bioresour. Technol. 146 (2013) 215-222. https://doi.org/10.1016/j.biortech.2013.07.070.

[31] T. Volova, E. Kiselev, O. Vinogradova, E. Nikolaeva, A. Chistyakov, A. Sukovatiy, E. Shishatskaya, A glucose-utilizing strain, Cupriavidus euthrophus B-10646: growth kinetics, characterization and synthesis of multicomponent PHAs, PLoS One. 9 (2014) 1-15. https://doi.org/10.1371/journal.pone.0087551.

[32] A.A. Olkhov, A.M. Goldshtrakh, G.E. Zaikov, A.L. Iordansky, Morphology of thermodynamic polyurethane and polyhydroxybutyrate blends, Vestnik tekhnologicheskogo universiteta (Bulletin of Technological University). 18, №7 (2015) 51-54 (in Russian).

[33] K.R. Shah, FTIR analysis of polyhydroxyalkanoates by novel Bacillus sp. AS 3-2 from soil of Kadi region, North Gujarat, India, J Biochem Technol. 3,4 (2012) 380-383.

[34] H. Bensalah, K. Gueraoui, H. Essabir, D. Rodrigue, R. Bouhfid and A.Qaiss, Mechanical, thermal, and rheological properties of polypropylene hybrid composites based clay and graphite//Journal of Composite Materials. 51 (2017) 1-14. https://doi.org/10.1177/0021998317690597.

[35] M. Bascaran, R. Hashim, N. Said, et al, Properties of binderless particleboard from oil palm trunk with addition of polyhydroxyalkanoates, Composites Part B: Engineering. 43 (2012) 1109-1116. https://doi.org/10.1016/j.compositesb.2011.10.008.

[36] M.K. Bin Bakri, E. Jayamani, S. Hamdan, Md. Rezaur Rahman, A. Kakar, Potential of Borneo Acacia wood in fully biodegradable bio-composites' commercial production and application, Polum Bull. (2018) 1-22. https://doi.org/10.1007/s00289-018-2299-9.

[37] M.K. Bin Bakri, E.Jayamani, S.K.Heng, A. Kakar, Potential Production of Acacia Wood and its Biocomposites, Materials Science Forum. 917 (2018) 37-41. ISSN: 1662-9752, https://doi.org/10.4028/www.scientific.net/MSF.917.37.

[38] B. Bittmann, R. Bouza, L. Barral, J. Diez, C. Ramirez, Poly (3-hydroxybutyrate-co3-hydroxyvalerate)/clay nanocomposites for replacement of mineral oil based materials, Polym. Compos. 34 (2013) 1033-1040. https://doi.org/10.1002/pc.22510. 
[39] R.M.D.S.M. Thiré, L.C. Arruda, L.S. Barreto, Morphology and thermal properties of poly(3-hydroxybutyrate-co-3-hydroxyvalerate)/attapulgite nanocomposites, Mater. Res. 14 (2011) 340-344. https://doi.org/10.1590/S1516-14392011005000046.

[40] Ali Harlin \& Minna Vikman (eds.), Developments in advanced biocomposites, Espoo, VTT Tiedotteita - Research Notes, 2010. 